Andrews University

Digital Commons @ Andrews University

1973

\title{
The Individual's Personality, His Exposure to E. G. White's Writings, and His Perception of E. G. White
}

Rainer K. P. Isecke

Andrews University

Follow this and additional works at: https://digitalcommons.andrews.edu/theses

Part of the Education Commons, and the Practical Theology Commons

\section{Recommended Citation}

Isecke, Rainer K. P., "The Individual's Personality, His Exposure to E. G. White's Writings, and His Perception of E. G. White" (1973). Master's Theses. 177.

https://dx.doi.org/10.32597/theses/177

https://digitalcommons.andrews.edu/theses/177

This Thesis is brought to you for free and open access by the Graduate Research at Digital Commons @ Andrews University. It has been accepted for inclusion in Master's Theses by an authorized administrator of Digital Commons@ Andrews University. For more information, please contact repository@andrews.edu. 


\title{
ABSTRACT OF GRADUATE STUDEIT RESTARCH
}

\section{Thesis}

\author{
Andrews University \\ Department of Education
}

Title: THE INDIVIDUAI'S PERSONAIITY, HIS EXPOSURE TO E. G. WHITE'S VRITINGS, AND HIS PERCEPTION OF "E. G. WHITE"

Name of researcher: Rainer $\mathbb{R}$. P. Iseche

Name of faculty advisers: Ruth R. Murdoch, Ed.D.;

Wilfred G. A. Futcher, Ph.D.; Conrad A. Reichert, Ph.D. Date completed: August 1973

\section{Problem}

E. G. White has been one of the most influential persons in the development of the Seventh-day Adventist Church. Therefore extremism in church members is likely to crystallize in issues concerning the implications of her writings for today. The purpose of this study was to explore what relation, if any, exists between certain personality traits of an individual, his exposure to E. G. White's yritings, and his perception of "E. G. White".

\section{Method}

The following instruments were used in the study: (1) The 
Questionnaire of Exposure to E. G. White; this questionnaire was developed to indicate the extent of an individual's exposure to $E$. $G$. White's writings and writings about her. (2) The scale of Attitudes toward "E. G. White"; this scale was developed for use in this study with the goal to distinguish between healthy positive and extreme positive attitudes toward "E. G. White". (3) The Rolreach Dogmatism Scale. (4) The Edwards Personality Inventory, boolilet III.

Two-vay analyses of variance-where categories of scores on the Rokeach Dogmatism Scale and/or on the different subscales of the Edwards Fersonality Inventory were the one independent variable, categories of scores on the Questionnaire of Exposure to $E$. G. White the other independent variable, and scores on the scales of Atiitudes toward "E. G. White" the dependent variable--were applied to the results in order to analyze the relationship between exposure to E. G. White's Writings, the individual's personality structure, and his attitudes toward "E. G. Thite".

Ninety-seven students from Andrews University Seminary, who held American citizenship and for whom English was the basic language, participated in one of several testing sessions.

Results

The only significant interaction effect was that between "Exposure to E. G. White" and "Cooperative". "Dogmatism", "Makes Friends Easily", and "Cooperative" were significantly related to scores on the Scale of Attitudes toward "E. G. White".

\section{Conclusions}

Perception of "E. G. White" seems to be partially influenced by the individual's personality structure and also to some degree by his exposure to $E$. G. Thite's rritings. Further research is needed in. this specific area; especially the impact of original E. G. White books, compilations of her statements, and books written about E. G. White need to be investigated with respect to the hypothesis that these different books influence the dogmatic person differently. 


\section{Andrews University}

School of Graduate Studies

THE INDIVIDUAL'S PERSONALITY, HIS EXPOSURE TO E. G. WHITE'S WRITINGS, AND HIS PERCEPTION OF "E. G. WHITE"

\section{A Thesis}

Presented in Partial Fulfillment

of the Requirements for the Degree

Master of Arts

by

Rainer K. P. Isecke

August 1973

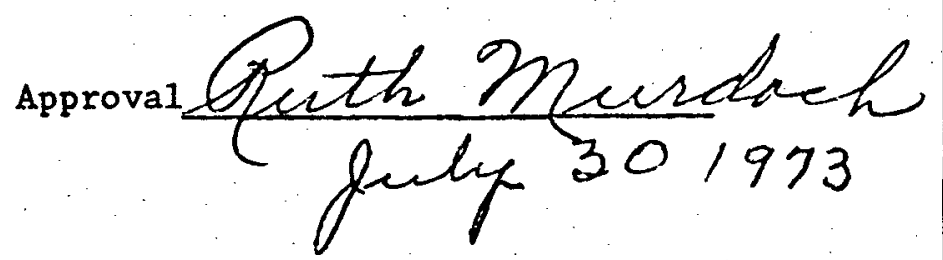


TABLE OF CONTENTS

Page

LIST OF TABLES . . . . . . . . . . . . . . . iv

Chapter

I. THE PROBLEM .................... 1

Introduction ............... 1

General Statement of the Problem ......... 2

Importance of the Study ............. 2

Limiting the Scope of the Study ......... 3

Statement of the Problem............ 4

Definition of Terms ............. 4

Hypotheses................ . . 4

II. REVIEW OF RELATED RESEARCH LITERATURE . . . . . . . 9

Basic Aspects of Personality and

Perception ................. . 9

Relevant Research Literature........ 10

Conclusions . . . . . . . . . . . . 12

III. RESEARCH DESIGN . . . . . . . . . . . 13

General Type of Research . . . . . . . . 13

Population and Sample ............ 13

Research Tools................ 13

Procedures .................. 16

IV. SCALE OF ATTITUDES TOWARD E. G. WHITE . . . . . 19

Purpose of the Scale . . . . . . . . 19

General Type of Scale .. . . . ...... 19

Content of the Items............. 19

Development of the Scale............. 21

v. ANALYSIS OF DATA . . . . . . . . . . . . 28

Method of Analysis . . . . . . . . . . . 28

Presentation of Data............. 29 
TABLE OF CONTENTS (Continued)

Chapter

Page

vi. SUMMARY AND CONCLUSIONS ................ 46

Summary ................. . . 46

Interpretation of Findings .......... 49

Scores on the Scale of Attitudes

Toward "E. G. White" . . . ........ 49

SAW Responses in Relation to Dogmatism ...... 53

SAW Responses in Relation to the "Cooperative"

Subscale of the EPI . . . . . . . . . . 55

SAW Responses in Relation to the "Makes

Friends Easily" Subscale of the EPI . . . . . 56

Suggestions for Further Research . . . . . . 58

APPENDIX . . . . . . . . . . . . . . 64

BIBLIOGRAPHY . . . . . . . . . . . . . . 81 
LIST OF TABLES

Table

Page

1. Scale of Attitudes Toward E. G. White, Pilot

Study, Analysis of Forms A and B . . . . . .

2. Scale of Attitudes Toward E. G. White,

Final Form . . . . . . . . . . . . . .

3. Scale of Attitudes Toward "E. G. White"

--Analysis of Final Form . . . . . . . . .

4. Analysis of Variance for Hypothesis III . . . . .

5. Means for Analysis of Variance for

Hypothesis III . . . . . . . . . . . .

6. Analysis of Variance for Hypothesis IV . . . . .

7. Means for Analysis of Variance for

Hypothesis IV

8. Analysis of Variance for Hypothesis V . . . . . 34

9. Means for Analysis of Variance for Hypothesis V . . 34

10. Analysis of Variance for Hypothesis VI . . . . . 35

11. Means for Analysis of Variance for Nypothesis VI . . . . . . . . . 35

12. Analysis of Variance for Hypothesis VII . . . . . 36

13. Means for Analysis of Variance for Hypothesis VII... . . . . . . . . 36

14. Analysis of Variance for Hypothesis VIII . . . . . 38

15. Means for Analysis of Variance for Hypothesis VIII . . . . . . . . . 38

16. Analysis of Varlance for Hypothesis IX . . . . . 39

17. Means for Analysis of Variance for

Hypothesis IX ....... . . . . . . . 


\section{LIST OF TABLES (Continued)}

Table

Page

18. Simple Effects Anslysis for Data of Analysis of Variance IX .......... 40

19. Analysis of Variance for Hypothesis X . . . . 42

20. Means for Analysis of Variance for

Hypothesis X. . . . . . . . . . . 42

21. Analysis of Variance for Hypothesis XI . . . . . 43

22. Means for Analysis of Variance for

Hypothesis XI .............. 43

23. Analysis of Variance for Hypothesis XII . . . . 45

24. Means for Analysis of Varlance for

Hypothesis XII . . . . . . . . . . 45

25. Structural Differences in the Distribution

of Scores on the SAW ........... 50 
CHAPTER I

THE PROBLEM

\section{Introduction}

During the latter part of the nineteenth century the Seventhday Adventist Church grew out of the Millerite Movement. From that time until the present one of the most influential factors in the development of the Church has been the person and writings of Ellen G. White. Her writings and books today still constitute the greater part of Seventh-day Adventist 1iterature. Possibly: the greatest impact of her person has not been that on organizational matters, but that upon the life-style of the members of the Seventh-day Adventist Church.

E. G. White's extraordinary position among Seventh-day Adventists rests on her claim of being inspired, tracing back most of her writings to Divine inspiration.

During her life much controversy among Seventh-day Adventists focused on the question of her being an inspired prophet or not. There is still some discussion about this question, but it seems that, among leaders of the Seventh-day Adventist Church--ministers, teachers, officials--the attitude of the great majority toward E. G. White and her writings is positive. Despite this there is still some controversy among church members concerning the 
implications of her writings for today. Sometimes these controversies hamper the growth of the Church.

Though the over-all position with respect to the Church's acceptance of E. G. White is positive, the question of concern is: what brings about these individual differences in views?

\section{General Statement of the Problem}

Until now very little study has been done in this specific area; a study by Thompson (1972) indicates that there is a difference in attitudes toward E. G. White and her writings among the students of two American Seventh-day Adventist Academies and one Norwegian Seventh-day Adventist High-School.

However an immense amount of study and theorizing have taken place in regard to the process of interaction between the organism and his environment. Could differences in psychological environment be a factor in shaping attitudes toward E. G. White and her writings?

The purpose of this study is to discover to what extent, if any, the attitude of individual church members toward the E. G. White writings is related to certain personality factors.

\section{Importance of the Study}

History shows that E. G. White was one of the most influential factors in the S.D.A. Church's development. Even if the attitudes of all individual church members toward the E. G. White writings were positive, there would still be differences 
between individuals, on a continuum ranging from a careful acceptance to an extreme, blind acceptance.

As it is easier to deal with a problem the underlying causes of which are known, the findings of this study should be of importance to the church as a whole, to leaders of youth, and to individual members.

\section{Limiting the Scope of the Study}

The findings of various basic studiesin the area of personality and perception may be applied to this problem in order to limit its scope. If the interaction of the individual with "E. G. White" is considered as taking place within the individual's total environment, three factors can be isolated which modify the interaction process:

a. the physical environment,

b. the amount and quality of E. G. White's writings, the individual is familiar with, and

c. the individual's personality structure. If a is controlled, differences in individual's perception of $E$. G. White's writings are due to differences in $b$ and $c$; for factor b this study was only concerned with the amount of E. G. White's writings the individual is familiar with; factor c could only be taken into consideration in segments as there is not yet an instrument that can claim to measure a personality structure in its totality. This study was concerned with personality traits which were assumed to modify the individual's perception of $E$. G. White and her writings. 
The process by which the individual in his interaction relates to "E. G. White", can be defined as perception and was inferred from his attitudes toward E. G. White and her writings.

\section{Statement of the Problem}

After limiting the scope of the problem it may be stated as follows:

How do certain personality-traits and exposure to E. G. White's writings relate to the individual's perception of "E. G. White"?

\section{Definition of Terms}

Certain Personality-Traits.--as measured by.

a. the Rokeach Dogmatism Scale, Form E, and

b. the Edwards Personality Inventory, Booklet III.

Exposure to E. G. White's Writings.--as measured by the

Questionnaire of Exposure to E. G. White (this questionnaire is given in the Appendix).

Perception of "E. G. White".--as measured by the Scalle of Attitudes toward "E. G. White". This attitude scale is described in Chapter IV.

\section{Hypotheses}

1. $\mathrm{H}_{1}$ : Between Exposure to E. G. White's writings and Certain Personality-Traits an interaction $F$ approaching significance will be found.

$\mathrm{H}_{0}$ : Between Exposure to E. G. White's writings and Certain Personality-Traits no interaction F approaching significance will be found: 
II. $\mathrm{H}_{1}$ : There is a difference on the Scale of Attitudes toward "E. G. White" (SAW) for groups on different levels on the Questionnaire of Exposure to E. G. White.

$\mathrm{H}_{\mathrm{O}}$ : There is no difference on the SAW for groups on different levels on the Questionnaire of Exposure to E. G. White.

III. $\mathrm{H}_{1}$ : If there is a positive difference between groups on the Rokeach Dogmatism Scale, then there will be a positive difference on the SAW.

$\mathrm{H}_{\mathrm{O}}$ : If there is a positive difference between groups on the Rokeach Dogmatism Scale, then there will be no difference or a negative difference on the SAW.

IV. $H_{1}$ : If there is a positive difference between groups on the "impressed by status" subscale of the Edwards Personality Inventory (EPI), then there will be a positive difference on the SAW.

$\mathrm{H}_{0}$ : If there is a positive difference between groups on the "impressed by status" subscale of the EPI, then there will be no difference or a negative difference on the SAW.

V. $\mathrm{H}_{1}$ : If there is a positive difference between groups on the "desires recognition" subscale of the EPI, then there will be a positive difference on the SAW.

$\mathrm{H}_{0}$ : If there is a positive difference between groups on the "desires recognition" subscale of the EPI, then 
there will be no difference or a negative difference on the SAW.

VI. $\mathrm{H}_{1}$ : If there is a positive difference between groups on the "feels superior" subscale of the EPI, then there will be a positive difference on the SAW.

$\mathrm{H}_{\mathrm{O}}$ : If there is a positive difference between groups on the "feels superior" subscale of the EPI, then there will be no difference or a negative difference on the SAW.

VII. $\mathrm{H}_{1}$ : If there is a positive difference between groups on the "self centered" subscale of the EPI, then there will be a positive difference on the SAW.

$\mathrm{H}_{\mathrm{O}}$ : If there is a positive difference between groups on the "self centered" subscale of the EPI, then there will be no difference or a negative difference on the SAW.

VIII. $\mathrm{H}_{1}$ : If there is a positive difference between groups on the "neat in dress" subscale of the EPI, then there will be a positive difference on the SAW.

$\mathrm{H}_{\mathrm{O}}$ : If there is a positive difference between groups on the "neat in dress" subscale of the EPI, then there will be no difference or a negative difference on the SAW.

IX. $\mathrm{H}_{1}$ : If there is a positive difference between groups on the "cooperative" subscale of the EPI, then there will be a negative difference on the SAW. 
$\mathbf{H}_{0}$ : If there is a positive difference between groups on the "cooperative" subscale of the EPI, then there will be no difference or a positive difference on the SAW.

X. $H_{1}$ : If there is a positive difference between groups on the "makes friends easily" subscale of the EPI, then there will be a negative difference on the SAW.

$\mathbf{H}_{0}$ : If there is a positive difference between groups on the "makes friends easily" subscale of the EPI, then there will be no difference or a positive difference on the SAW.

XI. $\mathrm{H}_{1}$ : If there is a positive difference between groups on the "independent in his opinion" subscale of the EPI, then there will be a negative difference on the SAW.

$\mathrm{H}_{0}$ : If there is a positive difference between groups on the "independent in his opinion" subscale of the EPI, then there will be no difference or a positive difference on the SAW.

XII. $\mathrm{H}_{1}$ : If there is a difference between groups on the "logical" subscale of the EPI, then there will be a difference on the SAW.

$\mathrm{H}_{\mathrm{O}}$ : If there is a difference between groups on the "logical" subscale of the EPI, then there will be no difference on the SAW. 
The reasons for stating hypotheses III - XI in the form of directional hypotheses can be inferred from Chapter II--Review of Related Research Literature. 
CHAPTER II

REVIEW OF RELATED RESEARCH LITERATURE

Basic Aspects of Personality and Perception

As the problem is the relation between the individual's personality and his perception of "E. G. White", this study dealt with three variables:
a. personality,
b. perception, and
c. "E. G. White"--the object of perception.
It is recognized that besides these there are other factors in the individual's psychological environment which shape his Interaction with "E. G. White", e.g., his parent's attitudes toward "E. G. White" in connection with their child rearing patterns. But these factors cannot be controlled in real life situation and it is assumed that at least part of them is reflected in the individual's personality.

It is outside the realm of this thesis to review basic literature on personality and perception. The interested reader should consult Bartley (1958), Allport (1955), Bruner and Postman (1948), Hebb (1949), Gibson (1950), Piaget (1932), Erikson (1963), Havighurst (1972), and Maslow (1968).

The following section discusses the findings of some recent studies which are rather similar to this study 
with respect to the basic problem. These were the basis for stating some of the hypotheses as directional hypotheses.

\section{Relevant Research Literature}

Hanson and Bush (1971) report that the scores of high anxiety Ss on form $E$ of the Rokeach Dogmatism Scale (DS) were significantly higher than those of low anxiety Ss.

Centers (1971) found that a high level of need for affiliation, nurturance, deference, intraception, dominance, succorance, and abasement were positively correlated with the positive evaluation of the partner the Ss were engaged with, while need for autonomy and aggression correlated negatively with positive evaluation of the partner.

Graff and Ladd (1971) report a negative correlation between scores on the Dimensions of Religious Commitment Scale and self acceptance and inner directedness as measured by the Personal Orientation Inventory.

Oswald (1970) arbitrarily divided Ss into: liberal, medium, and conservative groups according to their ranking on the Inventory of Theological Beliefs. Their scores on the Omnibus Personality Inventory and the DS then were compared. It turned out that the conservative group was lower on autonomy, disliked ambiguity, had a good opinion of self and was high on the DS. The liberal group was lower on the DS, more accepting of ambiguity, more anxious and had a poor opinion of self. The medium group was more or less in between. 
This finding seems to contradict the findings of Hanson and Bush (1971) and Graff and Ladd (1971). But a possible solution might be that a self accepting individual can take anxiety without becoming dogmatic, while the non accepting individual cannot face his anxiety and low confidence in his values without flight into dogmatism. The following supports this view: Laszlo and Rosenthal (1971) found that Ss high on the DS were significantly more susceptible to the influence of highstatus experimenters than Ss low on DS, whereas low-status experimenters could not influence high scorers on DS nor low scorers. As the experimenters were randomly assigned to low or high status without knowing about it, the finding indicates that a person high on DS is influenced by status, by personality, and less by objective facts. Anxiety and self-opinion of highly dogmatic persons thus can be seen as not being a function of the content of their beliefs but a function of status of important others.

Robbins (1970) conducted an experiment that heavily bears upon the problem of this study. Two groups, A and B, were formed by randomly assigned Ss scoring high on the DS. Groups C and D were formed by Ss low on the DS. Two contradicting descriptions of a person were given to them. Groups A and C first got one item that gave a positive description of the object; groups B and D first got one negative item. All groups had one minute time and then were asked to make a judgment about the object. Then all groups were given both full descriptions. When they thought they 
had enough information, they should write a final fudgment and Indicate their confidence in their judgment. It turned out that groups $A$ and $B$ (high on DS) upheld their initial judgment significantly more often than groups $C$ and D (1ow on DS), and were more confident in their judgment and used less information as basis for judging. Another finding is that group A (high on DS, got first positive item) modified judgment (positive) more easily than did group B (high on DS, got first negative item, leading to negative evaluation) with group B being more confident in judgment than group A.

\section{Conclusions}

There is considerable evidence that perception is a function of personality to a greater degree than it is a function of the object in focus or the stimulus.

The highly dogmatic person tends to judge other persons in his environment neutral or negative, but not positive, regardless of the validity of contradicting material. This might be an expression of his envy for status, because within an environment of neutrally or negatively evaluated persons he is much more likely to be the better evaluated person--the superior person, that of higher status. This feeling then will function in giving him security and status when he cannot accept himself as he is. 
CHAPTER III

\section{RESEARCH DESIGN}

\section{General Type of Research}

The purpose of this study was to find out if there is any. relation between certain personality traits of an individual, his exposure to E. G. White, and his attitudes toward "E. G. White". In order to accomplish this task, an explanatory survey research was carried out.

\section{Population and Sample}

The population was the future leaders of the S.D.A. Church in the United States of America as represented by the students of the Seminary at Andrews University who held American citizenship and for whom English was the basic language.

A sample of $147 \mathrm{Ss}$ was randomly selected. This sample had the limitation that the future teachers in S.D.A. schools were not included. It would be interesting to carry out the same study with Ss from the Education Department of Andrews University and to compare the results with the results of this study.

Research Tools

Scale of Attitudes toward "E. G. White". The purpose of this scale is to distinguish between Seventh-day Adventists holding 
"healthy positive" attitudes and those holding "extreme positive" attitudes--bordering on fanaticism--toward E. G. White and her writings.

The development and data of this scale are given in Chapter IV.

Questionnaire of Exposure to E. G. White. On this questionnaire the respondents indicate certain features of their exposure to E. G. White and her writings. In the following the type of exposure and the corresponding weights are given:

a. Are the parents Seventh-day Adventists?

Neither of them ............ 0

Father or mother ............. . 2

Both parents ............... 3

b. Education in S.D.A. schools, excluding Andrews

University Seminary; per year . . . . . . . $1 / 4$

Attendance at Andrews University Seminary;

per quarter ................ $1 / 3$

c. Attendance of the course CH570-HISTORY

OF THE SEVENTH-DAY ADVENTIST CHURCH . . . . . 3

Attendance of the course T570-PROPHETIC

GUIDANCE •. . . . . . . . . . . 7

d. Exposure to E. G. White books

Read a book partially ............. . 1

Read a book fully ................ 3

Read a book more than once ......... 4 
e. Exposure to books about E. G. White

Read a book partially .............. 1

Read a book fully ............... 2

Read a book more than once ......... 3

The points added yield the overall score. The weights of the different subscores were set up arbitrarily. The rationale for attaching the different weights was that type $d$ exposure should be given the heaviest impact on the overall score, as it is the most objective dimension of the factor "E. G. White", and that type $a$ and $b$ exposure should be given the least impact on the overall score, as it cannot be assumed safely that their influence points in the same direction as type $d$ exposure nor that they are uniform for different respondents.

Edwards Personality Inventory, Booklet III. This personality inventory is not one that has been widely used, which might be due to the fact that the author warned testers to use it only for research, as sufficient norms are not yet established. Besides this no test-retest reliability is given nor any correlations with scales from other inventories. The homogeneity of the scales is good, yielding $K-R 20$ reliability coefficients ranging from .65 to .95 , where thirty per cent of the coefficients are below .80 , forty per cent in the $180^{\prime} \mathrm{s}$, and thirty per cent above .90. A few of the scale's intercorrelation coefficients range up to the low $.80^{\prime} \mathrm{s}$, some are in the $.60^{\prime} \mathrm{s}$ and $.70 ' \mathrm{~s}$, but most lower, indicating that, in the main, they are measuring different aspects of personality. 
This inventory was chosen because of the relevance of the measured personality traits for this study.

Rokeach Dogmatism Scale, Form E. The author claims that this scale measures open- and closed-mindedness in general and therefore could be used for measuring a person's dogmatism in a fascistic, communistic, or any political organization, as well as in a religious setting. "This claim is supported by the Dogmatism Scale's correlation with the F Scale (Adorno, Frenkel-Brunswik, Levinson, and Sanford, 1950), yielding coefficients between .54 and .77 for different groups. While the Dogmatism Scale correlates rather highly with the absolute scores of Rokeach's Opiniation Scale, the correlation with the total score, when Left Opiniation is subtracted from Right Opiniation, is only between -.03 and .17 for different groups. The split-half reliability of form $E$ of the Dogmatism Scale is .81 for English College students and .78 for English workers.

Form $\mathrm{E}$ of the Dogmatism Scale was used because of the greater discrimination power of this shortened version.

\section{$\underline{\text { Procedures }}$}

The Dean of Andrews University Seminary, Dr. W. G. C. Murdoch, was asked for permission to conduct the study with Seminary students.

April 30, 1973 the study was announced in the Announcement Sheet of the Seminary which is distributed to every Seminary student. The next day a letter was sent to the random sample in 
which they were asked to come to the session. The text of the announcement and the letter are given in the appendix.

One hundred forty-seven Ss were chosen by using a table of random numbers. Ninety-six of these came to one of the sessions which were held on the following days: Friday, June 11, 9:00 A.M.; Monday, June 14, 7:00 P.M.; Tuesday, June 15, 9:30 A.M. and 2:00 P.M.; Thursday, June 17, 1:00 P.M.; Friday, June 18, 8:00 A.M.; and Monday, June 21, 12:30 P.M.

The reasons given by the 51 Ss who were invited but did not participate in the study were the following:

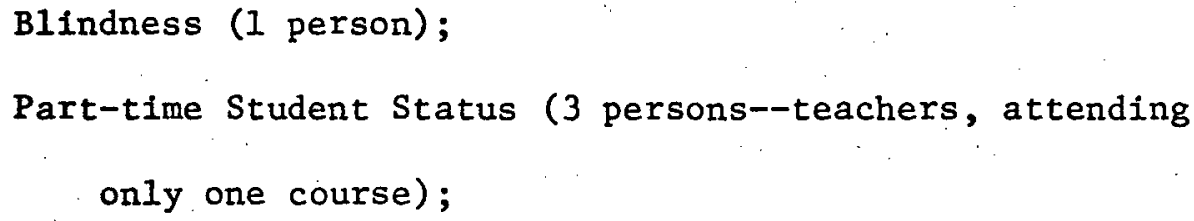

Non Avallability (2 persons were already moved away, 2 were In a hospital for surgery, 3 had to stay at home because of infections, and 40 persons could not come because of "lack of time").

The Ss were told that they did not need to indicate their names on the answer sheets; each $S$ got his answer sheets provided with a distinct number in order that the corresponding scores could be identified.

In the first session the instruments were administered in the following sequence: Edwards Personality Inventory, Rokeach Dogmatism Scale, Scale of Attitudes toward "E. G. White", Questionnaire of Exposure to E. G. White. For the other sesstons 
the sequence was changed in order to provide for the effects of fatigue as between one and two hours was required to fill in the answer sheets. 
Purpose of the Scale

The purpose of the Scale of Attitudes Toward E. G. White is to distinguish between Seventh-day Adventists holding "healthy, positive" attitudes and those holding "extreme, positive" attitudes --bordering on fanaticism--toward E. G. White.

\section{General Type of Scale}

The Scale of Attitudes Toward E. G. White is a Likert type scale with responses ranging from strongly agree--strongly disagree, where the point value for strongly agree $=1$, agree on the whole $=2$, agree a little $=3$, uncertain $=4$, disagree a little $=5$, disagree on the whole $=6$, and strongly disagree $=7$ for items, where agreement indicates. a "healthy" attitude. Where agreement indicates an "extreme" attitude, the point value scale is in reversed order.

\section{Content of the Items}

The items can be grouped accordingly. to reflect mainly three aspects of "healthy" versus "extreme" attitudes:

1. Aspect of Importance.

Items which reflect this aspect are competitive comparisons of E. G. White's.writings with other religlous literature (Bible) 
or statements concerning the importance of E. G. White books for the development of the individual's personality. It is assumed that the individual who holds "extreme" attitudes toward E. G. White will subscribe rigid importance to her writings more than the individual with "healthy" attitudes does.

2. Aspect of shifted purpose.

Items wich deal with this aspect distinguish between E. G. White's statements as a means to an end--to help mankind-and as an end in themselves--a restricting commandment. It is assumed that the individual with "extreme" attitudes will be more inclinced to perceive E. G. White's statements as an end in themselves than the person with "healthy". attitudes.

3. Aspect of Authoritarianism.

This includes two subaspects:

a. Aspect of careless generalization; items which reflect this aspect are generalizations of E. G. White's statements regardless of different circumstances. It is assumed that the individual who holds "extreme" attitudes toward E. G. White will tend to generalize in this way more easily than the individual with "healthy" attitudes.

b. Aspect of displaced authoritarianism; items which deal with this aspect relate the individual's authoritarian attitudes to E. G. White's statements. It is assumed, that the individual with "extreme" attitudes toward E. G. White expresses his authoritarian attitudes more easily than the person who 
holds "healthy" attitudes when he can rationalize his attitudes as being similar to E. G. White's.

\section{Development of the Scale}

A pool of 45 different items was developed; 37 of these then were stated in the opposite direction, so that 37 item pairs were obtained where each item pair had the same content, but one half stated the opposite direction to the other half.

The remaining 8 items-- 4 of them stated in one direction and 4 in the other direction--then were paired by randomly assigning 4 items of the one direction to the other 4 . By this means altogether 41 item pairs were obtained.

Now 2 item pairs were selected to serve as an honesty check; criteria for selection were a. best similarity of content, and $b$. best reversal of direction. These 2 item pairs were added to the pool so that in the end it contained 43 item pairs.

This procedure was followed because the goal was to build two forms, A and B, which contained items of the same content In the same order, but stated in the reverse direction. An Item analysis then could show which items were best in which direction.

By use of a table of random numbers the order of the items was achieved. Then for each item a coin was tossed to decide which half of an item pair was to be contained in form $A$ and which in form B. For the honesty check items this decision 
was made only with the item pairs arrived at first, because the arrangement of the two counterparts was determined by the former in that each form had to contain these items in both directions.

By these procedures the two forms $A$ and $B$ of the Scale of Attitudes Toward E. G. White as shown in the appendix were established.

A pilot study with these two forms was then run. The Ss were Undergraduates of Andrews University with majors in religion and theology. Form $\mathrm{A}$ was administered to $28 \mathrm{Ss}$ and form $\mathrm{B}$ to $30 \mathrm{Ss}$.

The data of the item analysis--using computation of Cronbach's Coefficient Alpha as a coefficient of internal con-. sistency--are shown in Table 1.

The final form of the Scale of Attitudes Toward E. G. White, as given in the appendix, consisted of the best items from forms $A$ and $B$; criterion for selection was a Point Multiserial Coefficient greater than .2000 (exception: item 18); when both item forms had a Point Multiserial Coefficient greater than .2000 , that with the greater Point Multiserial Coefficient was chosen.

Item 18 (20 on form B) was maintained as its Point Multiserial Coefficient was only slightly smaller than .2000 (.1952); It is assumed that this item's value was inflated by the term "necessarily" which in the final form was eliminated. 
TABLE 1

SCALE OF ATTITUDES TOWARD E. G. WHITE, PILOT STUDY, ANALYSIS OF FORMS A AND B

\begin{tabular}{|c|c|c|c|c|c|}
\hline \multirow{2}{*}{ Item } & \multicolumn{2}{|c|}{ Form A } & \multicolumn{2}{|c|}{ Form B } & \multirow{2}{*}{$\mathrm{D} *$} \\
\hline & $\mathbf{P}$ & $\mathbf{R}$ & $\mathbf{P}$ & $\mathbf{R}$ & \\
\hline 1 & .55 & .12 & 83 & .45 & + \\
\hline $2 * \star$ & .59 & .07 & .37 & -.05 & + \\
\hline 3 & .51 & .20 & .42 & .34 & + \\
\hline $4 * * *$ & .50 & .25 & .45 & .39 & - \\
\hline 5 & .56 & .16 & .43 & .37 & + \\
\hline 6 & .45 & .14 & .55 & .28 & + \\
\hline 7 & .52 & .00 & .77 & .36 & $=$ \\
\hline 8 & .40 & .16 & .34 & .10 & $=$ \\
\hline 9 & .39 & .19 & .46 & .54 & - \\
\hline 10 & .80 & .16 & .88 & .21 & + \\
\hline 11 & .66 & .41 & .73 & .34 & - \\
\hline 12 & .50 & .13 & .39 & .55 & + \\
\hline 13 & .68 & .42 & .82 & .30 & - \\
\hline $14 * * * *$ & .35 & .05 & .77 & .63 & - \\
\hline 15 & .40 & -.03 & .38 & .40 & - \\
\hline 16 & .48 & .23 & .55 & .40 & $\because$ \\
\hline 17 & .53 & .15 & .74 & .22 & + \\
\hline $18 * * * *$ & .55 & -.05 & .53 & .35 & - \\
\hline 19 & .57 & .33 & .50 & .40 & - \\
\hline 20 & .93 & .01 & .64 & .20 & + \\
\hline 21 & .49 & .34 & .50 & .55 & + \\
\hline 22 & .65 & .19 & .75 & .41 & - \\
\hline 23 & .54 & .11 & .52 & .39 & - \\
\hline 24 & .46 & .60 & .42 & .30 & - \\
\hline 25 & .61 & .47 & .66 & .42 & - \\
\hline 26 & .93 & .13 & .86 & .32 & + \\
\hline 27 & .18 & .01 & .21 & .06 & + \\
\hline 28 & 32 & .13 & .38 & .36 & - \\
\hline 29 & .39 & .19 & .65 & .49 & - \\
\hline 30 & .51 & .18 & .51 & .23 & + \\
\hline
\end{tabular}


TABLE 1 (Continued)

\begin{tabular}{|c|c|c|c|c|c|}
\hline \multirow{2}{*}{ Item } & \multicolumn{2}{|c|}{ Form A } & \multicolumn{2}{|c|}{ Form B } & \multirow{2}{*}{$D^{*}$} \\
\hline & $\mathbf{P}$ & $\mathbf{R}$ & $\mathbf{P}$ & $R$ & \\
\hline 31 & .68 & .34 & .58 & .43 & - \\
\hline 32 & .58 & .51 & .30 & -.11 & + \\
\hline 33 & .28 & .03 & .76 & .50 & - \\
\hline 34 & .67 & .23 & .58 & .49 & + \\
\hline 35 & .59 & .27 & .78 & .35 & $f$ \\
\hline 36 & .68 & .33 & .69 & .48 & - \\
\hline & .92 & .12 & .32 & .63 & - \\
\hline $38 * * \star *$ & .77 & .29 & .81 & .14 & - \\
\hline 39 & .52 & .08 & .56 & .26 & + \\
\hline 40 & .64 & .28 & .61 & .18 & + \\
\hline 41 & .50 & .05 & .78 & .48 & - \\
\hline $42 * * * *$ & .18 & .01 & .33 & .14 & - \\
\hline $43 * *$ & .36 & .05 & .55 & .58 & - \\
\hline $\mathrm{N}$ & & & & & \\
\hline & & & & & \\
\hline SD & & & & & \\
\hline$\alpha$ & & & & & \\
\hline
\end{tabular}

* Direction indicated by + : an individual with "unhealthy" attitudes was supposed to agree with this item on form $A$, but to disagree with it on form $B$; - indicates that an individual with "unhealthy" attitudes was supposed to disagree with this statement on form $A$, but to agree with it on form $B$.

** Items 2 and 43 were one item pair (honesty check).

*** Items 4 and 21 were one item pair (honesty check).

**** This item had not the same content on form $A$ and $B$.

REY: $\quad(P)=$ Proportion Score per Individual

(R) = Point Multiserial Coefficient

(D) = Direction of Item

$(\alpha)=$ Cronbach Coefficient Alpha

(N) = Number of Ss

(M) $=$ Mean

$(\mathrm{SD})=$ Standard Deviation 
As most items were chosen from form $B$, its structure was basically maintained. Where the form A item was selected because of its higher coefficient, it replaced the corresponding form B item.

Items $2,8,27,42$, and 43 were totally eliminated because they did not discriminate.

As items 2 and 43 were an honesty check item pair, item pair 25 was used as an additional honesty check with item 25A forming item 39 on the final form. Only one response on the scale was rejected because of contradiction showing up.

So the final form consisted of 39 items with items 3,19 and 23,39 as honesty checks. The ratio of items which an individual with "extreme" attitudes toward E. G. White is supposed to disagree with $(t)$ and to agree with $(-)$ is $19 / 20$. Table 2 shows which items from which form are contained in the final form and what their direction is. Table 3 gives the analysis of the final form as it was used in the study. 
TABLE 2

SCALE OF ATTITUDES TOWARD E. G. WHITE, FINAL FORM

\begin{tabular}{|c|c|c|c|c|c|}
\hline Item & $A / B$ & $D$ & Item & $\mathrm{A} / \mathrm{B}$ & $D$ \\
\hline 1 & $1 B$ & + & 21 & $23 B$ & - \\
\hline 2 & $3 B$ & + & 22 & $24 \mathrm{~A}$ & + \\
\hline 3 & $4 B$ & - & 23 & $25 B$ & - \\
\hline 4 & $5 B$ & + & 24 & $26 B$ & + \\
\hline 5 & $6 \mathrm{~B}$ & + & 25 & $28 \mathrm{~B}$ & - \\
\hline 6 & $7 B$ & - & 26 & $29 B$ & - \\
\hline 7 & $9 B$ & - & 27 & $30 \mathrm{~B}$ & + \\
\hline 8 & $10 B$ & + & 28 & $31 B$ & - \\
\hline 9 & $11 \mathrm{~A}$ & + & 29 & $32 \mathrm{~A}$ & - \\
\hline 10 & 12B & + & 30 & $33 B$ & - \\
\hline 11 & $13 \mathrm{~A}$ & + & 31 & $34 \mathrm{~B}$ & + \\
\hline 12 & $14 \mathrm{~B}$ & - & 32 & $35 B$ & + \\
\hline 13 & $15 B$ & - & 33 & $36 \mathrm{~B}$ & - \\
\hline 14 & $16 \mathrm{~B}$ & - & 34 & $37 \mathrm{~B}$ & - \\
\hline 15 & $17 \mathrm{~B}$ & + & 35 & $38 \mathrm{~A}$ & + \\
\hline 16 & $18 \mathrm{~B}$ & - & 36 & $39 B$ & + \\
\hline 17 & 19B & - & 37 & $40 \mathrm{~A}$ & - \\
\hline 18 & $20 \mathrm{~B}$ & + & 38 & $41 B$ & - \\
\hline 19 & $21 B$ & + & 39 & $25 \mathrm{~A}$ & + \\
\hline 20 & $22 B$ & - & & & \\
\hline
\end{tabular}

$($ ITEM $)=$ New Item Number

$(A / B)=$ Corresponding Item on Form $A$ or $B$

$(D,+/-)=$ Direction 
TABLE 3

SCALE OF ATTITUDES TOWARD "E. G. WHITE" --ANALYSIS OF FINAL FORM

\begin{tabular}{|c|c|c|c|c|c|}
\hline Item & $\mathbf{P}$ & $\mathbf{R}$ & Item & $\mathbf{P}$ & $\mathbf{R}$ \\
\hline $\begin{array}{l}1 \\
2 \\
3 \\
4 \\
5\end{array}$ & $\begin{array}{l}.89 \\
.55 \\
.41 \\
.47 \\
.65\end{array}$ & $\begin{array}{l}.25 \\
.42 \\
.53 \\
.38 \\
.16\end{array}$ & $\begin{array}{l}21 \\
22 \\
23 \\
24 \\
25\end{array}$ & $\begin{array}{l}.36 \\
.58 \\
.54 \\
.91 \\
.24\end{array}$ & $\begin{array}{l}.17 \\
.23 \\
.26 \\
.35 \\
.11\end{array}$ \\
\hline $\begin{array}{r}6 \\
7 \\
8 \\
9 \\
10\end{array}$ & $\begin{array}{r}.76 \\
.52 \\
.84 \\
.83 \\
.58\end{array}$ & $\begin{array}{l}.49 \\
.31 \\
.29 \\
.56 \\
.27\end{array}$ & $\begin{array}{l}26 \\
27 \\
28 \\
29 \\
30\end{array}$ & $\begin{array}{l}.60 \\
.58 \\
.62 \\
.69 \\
.79\end{array}$ & $\begin{array}{l}.39 \\
.45 \\
.45 \\
.40 \\
.45\end{array}$ \\
\hline $\begin{array}{l}11 \\
12 \\
13 \\
14 \\
15\end{array}$ & $\begin{array}{r}.76 \\
.80 \\
.32 \\
.47 \\
.72\end{array}$ & $\begin{array}{l}.01 \\
.32 \\
.32 \\
.35 \\
.14\end{array}$ & $\begin{array}{l}31 \\
32 \\
33 \\
34 \\
35\end{array}$ & $\begin{array}{l}.63 \\
.71 \\
.77 \\
.24 \\
.80\end{array}$ & $\begin{array}{l}.43 \\
.42 \\
.38 \\
.06 \\
.26\end{array}$ \\
\hline $\begin{array}{l}16 \\
17 \\
18 \\
19 \\
20\end{array}$ & $\begin{array}{l}.45 \\
.55 \\
.90 \\
.50 \\
.71\end{array}$ & $\begin{array}{l}.27 \\
.32 \\
.26 \\
.47 \\
.22\end{array}$ & $\begin{array}{l}36 \\
37 \\
38 \\
39\end{array}$ & $\begin{array}{l}.60 \\
.66 \\
.75 \\
.62\end{array}$ & $\begin{array}{l}.40 \\
.49 \\
.60 \\
.37\end{array}$ \\
\hline $\begin{array}{r}N \\
M \\
S D \\
\alpha\end{array}$ & $\begin{array}{r}94 \\
170.62 \\
24.23 \\
.80\end{array}$ & & & & \\
\hline
\end{tabular}

$\mathbf{P}=$ Proportion Score per Individual

$R=$ Point Multiserial Coefficient

$\mathrm{N}=$ Number of $\mathrm{Ss}$

$M=$ Mean

SD = Standard Deviation

$\alpha=$ Crombach Coefficient Alpha 


\section{CHAPTER V}

\section{ANALYSIS OF DATA}

The question of concern was if there was any relation between certain personality traits of an individual, his exposure to E. G. White, and his attitudes toward "E. G. White".

\section{Method of Analysis}

In order to answer the question of concern the hypotheses were tested by applying a two-way analysis of variance, where categories of scores on the Rokeach Dogmatism Scale and/or on the different subscales of the Edwards Personality Inventory were the one independent variable, categories of scores on the Questionnaire of Exposure to E. G. White the other independent variable, and scores on the Scale of Attitudes toward "E. G. White" the dependent variable.

The independent variables were each arbitrarily divided into three groups, Low, Medium, and High. The cut-off points were selected by considering the following three points:

a. to form groups of rather equal size, with the medium group preferably containing a few more Ss as the range of scores of the medium group normally is smaller than that of the other groups; 
b. to have Ss with equal scores in the same group; and

c. to obtain cells of rather equal size.

The unweighted means analysis for unequal cell frequencies was used to obtain the different F-ratios; in the case of a significant interaction $\mathrm{F}$ a simple effects analysis was carried out and the significance or non significance of differences between groups was determined by applying the Newman-Keuls method (Ferguson, 1971, PP. 272f.), in the case of a non significant interaction $F$, but significant $A$ and/or $B$ effect $F$, an overall effect analysis was carried out by using the Newman-Keuls method.

\section{Presentation of Data}

The presentation of data proceeds in the same sequence as the hypotheses were stated in chapter I; the same system of numbering is also used in order to facilitate reference to the corresponding hypotheses.

The vertical dimension for the different analyses of variance always represents the A effects (Exposure to E. G. White) whereas the horizontal dimension shows the B effects (Certain Personality Traits).

I. Interaction: The $\mathrm{H}_{\mathrm{O}}$ was upheld for all analyses of variance, except for analysis IX, where the $\mathrm{H}_{\mathrm{O}}$ was rejected and the $\mathrm{H}_{1}$ accepted. For further information see the specific analyses.

II. Exposure to E. G. White: The $\mathrm{H}_{\mathrm{O}}$ was upheld for all analyses of variance, except for analysis IX, where 
the $\mathrm{H}_{0}$ was rejected and the $\mathrm{H}_{1}$ accepted. For further information see the following analyses.

III. Exposure to E. G. White (A) - Dogmatism (B): $\mathrm{H}_{0}$ (I) was accepted and $\mathrm{H}_{1}$ (I) rejected as no significant Interaction $\mathrm{F}$ was found; the probability was .6966 . $\mathrm{H}_{0}$ (II) was accepted and $\mathrm{H}_{1}$ (II) rejected as no significant $A$ effects $F$ was obtained; its probability was .5664 . $\mathrm{H}_{\mathrm{O}}$ (III) was rejected and $\mathrm{H}_{1}$ (III) accepted as the $B$ effects $F$ was significant with a probability of .0132 ; the overall effects analysis showed that the difference between the High $B$ group and the Low $B$ group was significant at the .01 leve1 and between the Medium B group and the Low B group at the .05 level with no significant difference between the High B and Medium B group. The data are given in tables 4 and 5 .

IV. Exposure to E. G. White (A) - Impressed by status (B): $\mathrm{H}_{0}$. (I) was accepted and $\mathrm{H}_{1}$ (I) rejected as no significant Interaction $F$ was found; the probability was .9579 . $\mathrm{H}_{0}$ (II) was accepted and $\mathrm{H}_{I}$ (II) rejected as no significant A effects $F$ was obtained; its probability was .2328 . $H_{O}$ (IV) was accepted and $H_{1}$ (IV) rejected as the $B$ effects $F$ did not reach significance with its probability being . 3437. The data are given in tables 6 and 7. 
TABLE 4

ANALYSIS OF VARIANCE FOR HYPOTHESIS III

\begin{tabular}{ccccc} 
Exposure to E. G. White (A) & & Dogmatism (B) \\
\hline Source & M.S. & D.F. & F-Ratio & P \\
\hline Between & 936.08 & 8 & &. \\
A & 489.94 & 2 & .85 & .5664 \\
B & 2611.68 & 2 & 4.54 & .0132 \\
AB & 321.36 & 4 & .56 & .6966 \\
Within & 575.45 & 87 & & \\
\hline Total & 605.82 & 95 & & \\
\hline
\end{tabular}

TABLE 5

MEANS FOR ANALYSIS OF VARIANCE FOR HYPOTHESIS III

\begin{tabular}{lcccc}
\hline Group & High & Medium & Low & A Effects \\
\hline Low & 173.67 & 171.50 & 151.27 & 165.48 \\
Medium & 180.23 & 169.44 & 168.77 & 172.81 \\
High & 178.50 & 178.87 & 158.86 & 172.07 \\
\hline B Effects & 177.47 & 173.24 & 159.63 & \\
\hline
\end{tabular}


TABLE 6

ANALYSIS OF VARIANCE FOR HYPOTHESIS IV

\begin{tabular}{ccccc} 
Exposure to E. G. White (A) & \multicolumn{2}{c}{ Impressed by Status (B) } \\
\hline Source & M.S. & D.F. & F-Ratio & P \\
\hline Between & 454.83 & 8 & & \\
A & 936.19 & 2 & 1.48 & .2328 \\
B & 687.24 & 2 & 1.08 & .3437 \\
AB & 97.94 & 4 & .15 & .9579 \\
Within & 634.11 & 85 & & \\
\hline Total & 618.69 & 93 & & \\
\hline
\end{tabular}

TABLE 7

MEANS FOR ANALYSIS OF VARIANCE FOR HYPOTHESIS IV

\begin{tabular}{lcccc}
\hline \hline Group & High & Medium & Low & A Effects \\
\hline Low & 165.88 & 157.89 & 168.17 & 163.98 \\
Medium & 176.00 & 167.10 & 175.31 & 172.80 \\
High & 170.75 & 171.00 & 180.90 & 174.22 \\
\hline B Effects & 170.88 & 165.33 & 174.79 & \\
\hline
\end{tabular}


V. Exposure to E. G. White (A) - Desires recognition (B): $\mathrm{H}_{\mathrm{O}}$ (I) was accepted and $\mathrm{H}_{1}$ (I) rejected as no significant interaction $\mathrm{F}$ was found; the probability was .6073 . $\mathrm{H}_{\mathrm{O}}$ (II) was accepted and $H_{1}$ (II) rejected as no significant A effects $F$ was obtained; its probability was .5833 . $\mathrm{H}_{\mathrm{O}}(\mathrm{V})$ was accepted and $\mathrm{H}_{1}$ (V) rejected as the $\mathrm{B}$ effects $F$ was not significant with its probability being .9916. The data are given in tables 8 and 9.

VI. Exposure to E. G. White (A) - Feels superior (B): $\mathrm{H}_{0}$ (I) was accepted and $\mathrm{H}_{1}$ (I) rejected as no significant interaction $F$ was found; the probability was .1962 . $\mathrm{H}_{0}$ (II) was accepted and $\mathrm{H}_{1}$ (II) rejected as no significant $A$ effects $F$ was obtained; its probability was .3571. $\mathrm{H}_{\mathrm{O}}(\mathrm{VI})$ was accepted and $\mathrm{H}_{1}$ (VI) rejected as the B effects $F$ did not reach significance with its probability being .0661 . The data are given in tables 10 and 11.

VII. Exposure to E. G. White (A) - Self centered (B): $\mathrm{H}_{0}$ (I) was accepted and $\mathrm{H}_{1}$ (I) rejected as no significant interaction $F$ was found; the probability was .5932 . $\mathrm{H}_{0}$ (II) was accepted and $\mathrm{H}_{1}$ (II) rejected as no significant A effects $\mathrm{F}$ was obtained; its probability was .0980 . $\mathrm{H}_{0}$ (VII) was accepted and $\mathrm{H}_{1}$ (VII) rejected as the $B$ effects $F$ was not significant with its probability being .2863. The data are given in tables 12 and 13 . 
TABLE 8

ANALYSIS OF VARIANCE FOR HYPOTHESIS V

\begin{tabular}{crccc} 
Exposure to E. G. White (A) & & Desires Recognition (B) \\
\hline Source & M.S. & D.F. & F-Ratio & P \\
\hline Between & 361.13 & 8 & & \\
A & 567.24 & 2 & .89 & .5833 \\
B & 5.83 & 2 & .01 & .9916 \\
AB & 435.73 & 4 & .68 & .6073 \\
Within & 636.35 & 85 & & \\
\hline Total & 612.68 & 93 & &
\end{tabular}

TABLE 9

MEANS FOR ANALYSIS OF VARIANCE FOR HYPOTHESIS V

\begin{tabular}{lcccc}
\hline \hline Group & High & Medium & Low & A Effects \\
\hline Low & 163.30 & 161.64 & 174.00 & 166.31 \\
Medium & 177.69 & 174.36 & 166.82 & 172.96 \\
High & 171.89 & 179.57 & 173.07 & 174.84 \\
\hline B Effects & 170.96 & 171.86 & 171.30 & \\
\hline
\end{tabular}


TABLE 10

ANALYSIS OF VARIANCE FOR HYPOTHESIS VI

\begin{tabular}{ccccc} 
Exposure to E. G. White (A) & & \multicolumn{2}{c}{ Feels Superior (B) } \\
\hline Source & M.S. & D.F. & F-Ratio & P \\
\hline Between & 991.88 & 8 & & \\
A & 600.49 & 2 & 1.05 & .3571 \\
B & 1595.61 & 2 & 2.78 & .0661 \\
AB & 885.71 & 4 & 1.54 & .1962 \\
Within & 574.30 & 85 & & \\
\hline Total & 610.22 & 93 & & \\
\hline
\end{tabular}

TABLE 11

MEANS FOR ANALYSIS OF VARIANCE FOR HYPOTHESIS VI

\begin{tabular}{lcccc}
\hline Group & High & Medium & Low & A Effects \\
\hline Low & 145.82 & 177.36 & 174.71 & 165.97 \\
Medium & 170.23 & 170.36 & 179.55 & 173.38 \\
High & 172.43 & 174.25 & 175.36 & 174.01 \\
\hline B Effects & 162.83 & 173.99 & 176.54 & \\
\hline
\end{tabular}


TABLE 12

ANALYSIS OF VARIANCE FOR HYPOTHESIS VII

\begin{tabular}{ccccc} 
Exposure to E. G. White (A) & & \multicolumn{2}{c}{ Self Centered (B) } \\
\hline Source & M.S. & D.F. & F-Ratio & P \\
\hline $\begin{array}{c}\text { Between } \\
\text { A }\end{array}$ & 767.00 & 8 & & \\
B & 1439.12 & 2 & 2.37 & .0980 \\
AB & 770.85 & 2 & 1.27 & .2863 \\
Within & 429.01 & 4 & .71 & .5932 \\
\hline Total & 608.22 & 85 & & \\
\hline
\end{tabular}

TABLE 13

MEANS FOR ANALYSIS OF VARIANCE FOR HYPOTHESIS VII

\begin{tabular}{lllll}
\hline Group & High & Medium & Low & A Effects \\
\hline Low & 161.90 & 153.00 & 171.46 & 162.12 \\
Medium & 169.73 & 178.67 & 173.42 & 173.94 \\
High & 171.71 & 168.54 & 183.40 & 174.55 \\
\hline B Effects & 167.78 & 166.74 & 176.09 & \\
\hline
\end{tabular}


VIII. Exposure to E. G. White (A) - Neat in dress (B):

$\mathrm{H}_{\mathrm{O}}$ (I) was accepted and $\mathrm{H}_{1}$ (I) rejected as no significant interaction $F$ was found the probability was .2413. $\mathrm{H}_{\mathrm{O}}$ (II) was accepted and $\mathrm{H}_{1}$ (II) rejected as no significant $A$ effects $F$ was obtained; its probability was .5289 . $\mathrm{H}_{0}$ (VIII) was accepted and $\mathrm{H}_{1}$ (VIII) rejected as the $B$ effects $F$ was not significant with its probability being .6071 . The data are given in tables 14 and 15 .

IX. Exposure to E. G. White (A) - Cooperative (B): $\mathrm{H}_{0}$ (I) was rejected and $\mathrm{H}_{1}$ (I) accepted as a significant interaction $F$ was found; the Probability was .0176 . $\mathrm{H}_{\mathrm{O}}$ (II) was rejected and $\mathrm{H}_{1}$ (II) accepted though no significant A effects $F$ was found; its probability was .2757; but this was due to the significant interaction; the simple effects analysis yielded significant differences between certain groups. $\mathrm{H}_{\mathrm{O}}$ (IX) was accepted and the $\mathrm{H}_{1}$ (IX) rejected though a highly significant $B$ effects $F$ was obtained with its probability being .004 ; but the direction contradicted hypothesis IX. The data are given in tables 16 and 17 . The simple effects analysis was carried out for all levels of $A$ and $B$; where a significant $F$ was found the significance of differences between groups was determined by using the Newman-Keuls method. The results for the different levels are shown in table 18. 
TABLE 14

ANALYSIS OF VARIANCE FOR HYPOTHESIS VIII

\begin{tabular}{ccccc} 
Exposure to E. G. White (A) & \multicolumn{2}{c}{ Neat in Dress (B) } \\
\hline Source & M.S. & D.F. & F-Ratio & P \\
\hline Between & 678.92 & 8 & & .77 \\
A & 462.58 & 2 & .5289 \\
B & 572.04 & 2 & .95 & .6071 \\
AB & 840.52 & 4 & 1.40 & .2413 \\
Within & 602.17 & 85 & & \\
\hline Total & 608.77 & 93 & & \\
\hline
\end{tabular}

TABLE 15

MEANS FOR ANALYSIS OF VARIANCE FOR HYPOTHESIS VIII

\begin{tabular}{lcccc}
\hline Group & High & Medium & Low & A Effects \\
\hline Low & 172.45 & 178.17 & 150.00 & 166.87 \\
Medium & 174.91 & 171.78 & 172.80 & 173.16 \\
High & 174.11 & 172.200 & 176.18 & 174.16 \\
\hline B Effects & 173.82 & 174.05 & 166.33 & \\
\hline
\end{tabular}


TABLE 16

ANALYSIS OF VARIANCE FOR HYPOTHESIS IX

\begin{tabular}{lcccc} 
Exposure to E. G. White (A) & \multicolumn{2}{c}{ Cooperative (B) } \\
\hline Source & M.S. & D.F. & F-Ratio & P \\
\hline Between & 2009.58 & 8 & & \\
A & 621.02 & 2 & 1.31 & .2757 \\
B & 4402.34 & 2 & 9.25 & .0004 \\
AB & 1507.47 & 4 & 3.17 & .0176 \\
Within & 475.81 & 85 & & \\
\hline Total & 607.75 & 93 & &
\end{tabular}

TABLE 17

MEANS FOR ANALYSIS OF VARIANCE FOR HYPOTHESIS IX

\begin{tabular}{lllll}
\hline Group & High & Medium & Low & A Effects \\
\hline Low & 180.25 & 178.30 & 140.09 & 166.21 \\
Medium & 187.70 & 175.69 & 158.67 & 174.02 \\
High & 170.91 & 177.42 & 174.00 & 174.11 \\
\hline B Effects & 179.62 & 177.14 & 157.59 & \\
\hline
\end{tabular}


TABLE 18

SIMPLE EFFECTS ANALYSIS FOR DATA OF ANALYSIS OF VARIANCE IX

\begin{tabular}{|c|c|c|c|c|c|c|}
\hline Leve1. & Source & M.S. & D.F. & F-Ratio & Sign. I & Diff. \\
\hline A Low & $\begin{array}{l}\text { Between } \\
\text { Within }\end{array}$ & $\begin{array}{r}5221.02 \\
588.71\end{array}$ & $\begin{array}{r}2 \\
26\end{array}$ & $8.87 * x$ & $\begin{array}{l}\text { High } \\
\text { Medium }\end{array}$ & $\begin{array}{l}\text { - Low** } \\
\text { - Low* }\end{array}$ \\
\hline A Medium & $\begin{array}{l}\text { Between } \\
\text { Within }\end{array}$ & $\begin{array}{r}2808.80 \\
356.30\end{array}$ & $\begin{array}{r}2 \\
32\end{array}$ & $7.88 * *$ & $\begin{array}{l}\text { High } \\
\text { High } \\
\text { Medium }\end{array}$ & $\begin{array}{l}\text { - Low** } \\
\text { - Medium* } \\
\text { - Low* }\end{array}$ \\
\hline A High & $\begin{array}{l}\text { Between } \\
\text { Within }\end{array}$ & $\begin{array}{l}121.77 \\
475.40\end{array}$ & 27 & .26 & & \\
\hline B High & $\begin{array}{l}\text { Between } \\
\text { Within }\end{array}$ & $\begin{array}{r}1193.64 \\
394.56\end{array}$ & $\begin{array}{r}2 \\
26\end{array}$ & $3.03^{a}$ & & \\
\hline B Medium & $\begin{array}{l}\text { Between } \\
\text { Within }\end{array}$ & $\begin{array}{r}20.59 \\
355.68\end{array}$ & $\begin{array}{r}2 \\
32\end{array}$ & .06 & & \\
\hline B Low & $\begin{array}{l}\text { Between } \\
\text { Within }\end{array}$ & $\begin{array}{r}2563.90 \\
663.10\end{array}$ & $\begin{array}{r}2 \\
27\end{array}$ & $3.87 *$ & $\begin{array}{l}\text { High } \\
\text { High } \\
\text { Medium }\end{array}$ & $\begin{array}{l}\text { - Low** } \\
\text { - Medium* } \\
\text { - Low* }\end{array}$ \\
\hline
\end{tabular}

* F-Ratio is significant at .05 level; difference between groups is significant at .05 level.

** F-Ratio is significant at .01 level; difference between groups is significant at .01 level.

a F-Ratio nearly reached significance; the required $F^{\prime}$ at the .05 level was 3.37 . 
X. Exposure to E. G. White (A) - Makes friends easily (B): $\mathrm{H}_{0}$ (I) was accepted and $\mathrm{H}_{1}$ (I) rejected as no significant interaction $F$ was found; the probability was .8198 . $\mathrm{H}_{0}$ (II) was accepted and $\mathrm{H}_{1}$ (II) rejected as no significant A effects $F$ was obtained; its probability was .1566. $\mathrm{H}_{\mathrm{O}}(\mathrm{X})$ was accepted and $\mathrm{H}_{1}(\mathrm{X})$ rejected though a highly significant B. effects $F$ was obtained with its probability being .0011 ; but the direction contradicted hypothesis $\mathrm{X}$. The overall effects analysis for B yielded differences between the High B group and the Low B group, and between the Medium B group and the Low B group, which were significant at the .01 level with no significant difference between the High B group and the Medium B group. The data are given in tables 19 and 20.

XI. Exposure to E. G. White (A) - Independent in his opinion (B): $H_{0}$ (I) was accepted and $H_{1}$ (I) rejected as no significant interaction $\mathrm{F}$ was found; the probability was .2011. $\mathrm{H}_{\mathrm{O}}$ (II) was accepted and $H_{1}$ (II) rejected as no significant $A$ effects $F$ was obtained; its probability was $.5624 . \mathrm{H}_{0}(\mathrm{XI})$ was accepted and $\mathrm{H}_{1}$ (XI) rejected as the $B$ effects $F$ was not significant with its probability being .2682. The data are given in tables 21 and 22 . 
TABLE 19

ANALYSIS OF VARIANCE FOR HYPOTHESIS $X$

\begin{tabular}{ccccc} 
Exposure to E. G. White (A) & & Makes Friends Easily (B) \\
\hline Source & M.S. & D.F. & F-Ratio & P \\
\hline Between & 1414.07 & 8 & & \\
A & 1021.55 & 2 & 1.88 & .1566 \\
B & 4215.84 & 2 & 7.77 & .0011 \\
AB & 209.44 & 4 & .39 & .8198 \\
Within & 542.91 & 85 & & \\
\hline \\
Total
\end{tabular}

TABLE 20

MEANS FOR ANALYSIS OF VARIANCE FOR HYPOTHESIS X

\begin{tabular}{llccc}
\hline Group & High & Medium & Low & A Effects \\
\hline Low & 176.20 & 168.11 & 149.10 & 164.47 \\
Medium & 184.71 & 179.07 & 160.23 & 174.67 \\
High & 176.36 & 183.67 & 163.40 & 174.48 \\
\hline B Effects & 179.09 & 176.95 & 157.58 & \\
\hline
\end{tabular}


TABLE 21

ANALYSIS OF VARIANCE FOR HYPOTHESIS XI

\begin{tabular}{ccccc} 
Exposure to E. G. White (A) & \multicolumn{3}{c}{ Independent in His Opinion (B) } \\
\hline Source & M.S. & D.F. & F-Ratio & P \\
\hline Between & 702.94 & 8 & & \\
A & 332.97 & 2 & .59 & .5624 \\
B & 754.04 & 2 & 1.33 & .2682 \\
AB & 862.37 & 4 & 1.52 & .2011 \\
Within & 565.54 & 85 & & \\
\hline Total & 577.36 & 93 & & \\
\hline
\end{tabular}

TABLE 22

MEANS FOR ANALYSIS OF VARIANCE FOR HYPOTHESIS XI

\begin{tabular}{lcccc}
\hline Group & High & Medium & Low & A Effects \\
\hline Low & 151.45 & 173.83 & 178.33 & 167.87 \\
Medium & 173.62 & 168.50 & 178.30 & 173.47 \\
High & 173.00 & 178.55 & 170.00 & 173.85 \\
\hline B Effects & 166.02 & 173.63 & 175.54 & \\
\hline
\end{tabular}


XII. Exposure to E. G. White (A) - Logical (B):

$\mathrm{H}_{\mathrm{O}}$ (I) was accepted and $\mathrm{H}_{1}$ (I) rejected as no significant interaction $F$ was found; the probability was $.1480 . \mathrm{H}_{\mathrm{O}}$ (II) was accepted and $\mathrm{H}_{\mathrm{O}}$ (II) rejected as no significant A effects $F$ was obtained; its probability was .2469 . $\mathrm{H}_{\mathrm{O}}$ (XII) was accepted and $\mathrm{H}_{1}$ (XII) rejected as the $\mathrm{B}$ effects $\mathrm{F}$ was not significant with its probability being .3456 . The data are given in rables 23 and 24 . 
TABLE 23

ANALYSIS OF VARIANCE FOR HYPOTHESIS XII

Exposure to E. G. White (A)

Logical (B)

\begin{tabular}{ccccc}
\hline Source & M.S. & D.F. & F-Ratio & P \\
\hline Between & 874.01 & 8 & & \\
A & 829.56 & 2 & 1.42 & .2469 \\
B & 631.32 & 2 & 1.08 & .3456 \\
AB & 1017.58 & 4 & 1.74 & .1480 \\
Within & 484.42 & 85 & & \\
\hline Total & 610.25 & 93 & & \\
\hline
\end{tabular}

TABLE 24

MEANS FOR ANALYSIS OF VARIANCE FOR HYPOTHESIS XII

\begin{tabular}{lllll}
\hline \hline Group & High & Medium & Low & A Effects \\
\hline Low & 180.40 & 154.50 & 157.44 & 164.11 \\
Medium & 175.88 & 177.33 & 165.20 & 172.81 \\
High & 168.67 & 176.55 & 175.20 & 173.47 \\
\hline B Effects & 174.98 & 169.46 & 165.95 & \\
\hline
\end{tabular}


CHAPTER VII

SUMMARY AND CONCLUSIONS

Summary

The basic question of this study was what relation, if any, exists between certain personality traits of an individual, his exposure to E. G. White, and his perception of "E. G. White".

Theories of personality and perception suggest that perception is a function of personality and the object in focus-the stimulus.

In this context it was assumed that the individual's perception of "E. G. White"--inferred from his attitudes toward "E. G. White"--is basically determined by his personality structure and the amount and quality of E. G. White's writings he is familiar with.

In reference to the basic problem this study was limited in the following three points: (1) attitudes toward "E. G. White" were limited to the distinction between healthy positive attitudes and extreme positive attitudes, (2) personality structure was limited to personality traits as measured by the Rokeach Dogmatism Scale and the Edwards Personality Inventory, booklet three, and (3) the quality of E. G. White's writings the individual was familiar with was neglected and only the amount was taken into consideration. 
Attitudes toward "E. G. White" were measured by the Scale of Attitudes toward "E. G. White" which was developed as a Likert type scale containing thirty-nine items. The final form was derived from two forms $A$ and $B$ for which a pilot study yielded reliability coefficients of .62 and .85 respectively; the final version's reliability coefficient was .80 with its standard deviation being 24.23 .

Exposure to E. G. White was measured by the Questionnaire of Exposure to E. G. White. This yielded a score which was a function of the respondent's exposure to E. G. White's writings, writings about her, and instruction about her role in the development of the early Seventh-day Adventist Church.

The population of the study was the future leaders of the S.D.A. church in the United States as represented by the students of Andrews University Seminary who held American citizenship and for whom English was the basic language. One hundred forty-seven Ss were randomly chosen and invited to participate in the session; 96 of these came to one of the testing sessions which were conducted at different times within a 10 days' range.

Two-way analyses of variance--where categories of scores on the Rokeach Dogmatism Scale and/or on the different subscales of the Edwards Personality Inventory were the one independent variable, categories of scores on the Questionnaire of Exposure to E. G. White the other independent variable, and scores on the Scale of Attitudes toward "E. G. White" the dependent variable--were applied to the results in order to test twelve 
hypotheses, the null hypotheses of which are briefly indicated in the following:

I. No significant interaction $F$ will be found.

II. There will be no difference on the Scale of Attitudes toward "E. G. White" (SAW) for groups with different scores on the Questionnaire of Exposure to E. G. White.

There will be a negative or no difference on the SAW between groups which differ positively on the

III. Rokeach Dogmatism Scale,

IV. "impressed by status" subscale of the Edwards Personality Inventory (EPI),

V. "desires recognition" subscale of the EPI,

VI. "feels superior" subscale of the EPI,

VII. "self centered" subscale of the EPI, and the

VIII. "neat in dress" subscale of the EPI. There will be a positive or no difference on the SAW between groups which differ positively on the

IX. "cooperative" subscale of the EPI,

X. "makes friends easily" subscale of the EPI, and

XI. "independent in his opinion" subscale of the EPI.

XII. There will be no difference on the SAW for groups with different scores on the "logical" subscale of the EPI.

of these twelve null hypotheses one (III) was rejected, two (I and II) were rejected in relation to analysis IX but not to the others; two (IX and $\mathrm{X}$ ) were accepted though the corresponding 
analyses of data yielded highly significant differences; but these contradicted the direction of the hypotheses. The remaining null hypotheses (IV, V, VI, VII, VIII, XI, and XII) were accepted. These findings will be discussed in the following section and a solution to the startling outcome (IX and $\mathrm{X}$ ) will be suggested. The overall results affirm the assumption that the individual's perception of "E. G. White" to a great degree is influenced by his personality structure and to some degree by the exposure to E. G. White.

\section{Interpretation of Findings}

Scores on the Scale of Attitudes Toward "E. G. White"

The possible range of scores on the final form of the Scale of Attitudes toward "E. G. White" (SAW) is from 39 to 273. The actual range in this study was from 97 to 227 with the mean being 170.62 and a standard deviation of 24.23 .

As this was the first time that the SAW has been used these results cannot be compared with other studies; but an attempt will be made to compare the results of the pilot study with the final study. In doing this it must be remembered that it is not the results of the same instrument which are being compared; it is assumed that, despite this structural difference, the results can be interpreted as it is basically the same instrument, be it form A or B as used for the pilot study or the final version used for this study. 
An inspection of Table 25 shows that there is a structural difference between the pilot study (forms $A$ and $B$ ) and the final study (final version $F$ ) in the distribution of scores with respect to two aspects: (1) the actual means of scores in the pilot study were nearly equal to or lower than the arithmetic mean of the possible scores whereas in the final study the actual mean of scores was higher than the mean possible score, and (2) the range of the upper half scores in the pilot study was wider than the range of the lower half scores whereas in the final study (F) the opposite was true.

\section{TABLE 25}

STRUCTURAL DIFFERENCES. IN THE DISTRIBUTION OF SCORES ON THE SAW

\begin{tabular}{ccccc}
\hline \hline Form & $\begin{array}{c}\text { Mean } \\
\text { Possible } \\
\text { Score }\end{array}$ & $\begin{array}{c}\text { Actual } \\
\text { Means }\end{array}$ & $\begin{array}{r}\text { Range } \\
\text { Upper } \\
\text { Half }\end{array}$ & $\begin{array}{r}\text { Range } \\
\text { Lower } \\
\text { Half }\end{array}$ \\
\hline A & 172.00 & 163.64 & 51 & 34 \\
B & 172.00 & 172.47 & 73 & 59 \\
F & 156.00 & 170.62 & 55 & 74 \\
\hline
\end{tabular}

These differences indicate that the sample involved in the final study as a group had more extreme attitudes toward "E. G. White" than the sample involved in the pilot study. What might be the reason for this?

It is assumed that the samples for the pilot study and the final study were drawn from the same population as the Ss in the 
pilot study were religion and theology majors attending Andrews University College and the $\mathrm{Ss}$ in the final study were students attending Andrews University Seminary.

One possible explanation of the different scoring patterns could be thought of in terms of different quality of instruction, that is the Seminary might indoctrinate a more extreme view concerning E. G. White than the College does. But the results of the analysis of variance IX seem to contradict this explanation, as will be discussed in that context.

Another--more reasonable--explanation grew out of the examination of the SAW scores of the final study in relation to the fact that only 97 of the invited 147 ss responded to the invitation to participate in the study and that only 37 Ss appeared at the initially scheduled testing session; the others responded not before they were invited once, twice, or even three times in addition to the letter by being called up and urged to come.

It seemed that the group which came to the initial session was more extremely positive in attitudes toward "E. G. White" than the other groups.

This finding is in line with the hypothesis put forward by Kelley (1972) that churches which today in the United States are still growing--and he lists the S.D.A. church among those--reveal among other more favorable traits, like willingness for sacrifice and concern for others, a certain amount of fanaticism.

It was assumed that those who were least willing to respond to the invitations (those who did not show up at all without 
reasonable excuse) as a group were those with the least extreme attitudes toward "E. G. White".

In order to test this hypothesis an attempt was made to get a random sample of 20 Ss of those who did not come despite several invitations. Fifteen of those 20 Ss could be contacted and 13 promised to come; actually 3 of these came and scored well below average on the SAW.

But as this number was too small, two groups were compared, the one of which consisted of the 35 Ss who came to the initial session (2 Ss were excluded from this group as the honesty check indicated that their responses were not consistent) and the other was composed of those 62 Ss who came to the sessions following the initial one, including those $3 \mathrm{Ss}$ from the later conducted session and excluding $1 \mathrm{~S}$ because of inconsistency as indicated by the honesty check.

The mean of the first group's scores $(\mathrm{N}=35)$ was 182.89 whereas the mean of the second group's scores $(N=62)$ was 162.13 . The applied t-test yielded a highly significant $t(6.71)$; for a two-tailed test the required $t$ at the .001 level is 3.41 .

The assumption that those who were invited to the study but who did not show up were the ones with the least extremely positive attitudes toward E. G. White seems to be affirmed by this finding and this would explain the difference in structural patterns between the pilot study and the final study as in the pilot study the SAW was administered to the Ss during regular class time whereas in the final study the Ss were required to spend some of 
their free time. In the pilot study then all chosen Ss responded because they could not use this time for doing other things; for the final study the invited Ss first had to make up their mind if it was important enough to them to participate in it or not; naturally those who cared the least about their relation to "E. G. White" were more inclined to spend their time doing something else, something more important to them.

This placing of great emphasis on specific matter, in this case on the importance of E. G. White might be termed fanaticism. But it is doubtful that this application of "fanaticism" is psychologically sound; it can as well be described as zeal, as having values, as pursuing goals, and by this directing ones 1ife. True fanaticism, or dogmatism, as Rokeach (1960) calls it, is indicated by the existence of communication barriers between subaspects of ones belief-disbelief system. This incon: sistency in ones value system often goes together with emphasizing specific matters--and this might have led Kelley (1972) to the conclusion that churches that today want to grow in the United States must allow for a certain amount of fanaticism--but it does not necessarily do so.

To avoid confusion over the meaning of the term fanaticism the term "narrow extremism" will be used.

\section{SAW Responses in Relation to Dogmatism}

The possible range of scores on form $E$ of the Rokeach Dogmatism Scale (DS) is from 40 to 280 . The actual range in this 
study was from 88 to 221 with the mean being 170.91 and a standard deviation of 24.64 .

This indicates that the population of this study is rather distinct from "normal" population at a comparable educational level, as other studies with College- and Graduate-students generally yield means around 142 (Rokeach, 1960).

What is this difference due to? Is it that the population of this study is more closed minded than other groups are? Another cause might be that Seventh-day Adventists are bound to score high on some items of the DS because of their distinct philosophy of life. The positive response to these items does not indicate a self defense against poor adjustment for Seventh-day Adventists or groups of similar philosophical background, but a genuine concern for social and religious matters.

Analysis of variance III showed that the SAW scores of the groups high and medium on the DS were significantly higher than those of the group low on the DS.

The question that comes to mind at this point is: Are the SAW and the DS measuring the same factor or do they measure different but positively related factors? The importance of this question will be discussed in the last section of this chapter. At this point it will only be noted that dogmatism or closed mindedness alone do not seem to account for all differences between responses on the SAW. It will be recalled that there was a highly significant difference between the SAW responses of those Ss who came to the initially scheduled session and those 
coming to the later sessions. The DS responses of these groups were checked too. The first group's mean (174.43) was slightly higher than that of the later groups $(168.88)$ but this difference was far from reaching significance $(t=1.06 ; D F=94)$. Another point that should be kept in mind, as it will be discussed in the last section, is that no significant difference between the groups high and medium on the DS was found in respect to their SAW scores.

SAW Responses in Relation to the "Cooperative" Subscale of the EPI

It was hypothesized that the group higher on the "cooperative" subscale of the EPI would be lower on the SAW. But the analysis of data completely contradicted the direction of the $H_{1}$ at a significance level beyond .001 . Is there an explanation to this finding? The rationale behind $H_{1}$ IX was that the dogmatic person is unlikely to cooperate because: (1) his acceptance of others is conditional (Rokeach, 1960), (2) his decisions are more susceptible to be modified by authority figures than by peer groups or relevant but contradicting facts (Laszlo and Rosentha1, 1971; Robbins, 1971), and (3) he tends to perceive others as inferior (Robbins, 1971).

In this context the meaning of "cooperative" was to have an accepting, helpful attitude toward others.

An examination of the items of the "cooperative" scale revealed a quite different meaning: "cooperative" seems to be equated with submissive, uncritical acceptance of instrumental authority. Three sample items are given below:

29. He is usually in agreement with the opinions of his superiors. 
163. He usually takes the advice offered to him by anyone In a position of authority.

212. He willingly performs little services for people in a position of authority.

If "cooperative" is used in this context the finding that the more "cooperative" group is the more extreme group becomes understandable, should even be expected.

Interesting is the finding of an interaction $F$, significant almost at the .01 level; but as the A effect (Exposure to E. G. White) in no case reached significance and only in this case a significant interaction $F$ was obtained, it should not be stressed too heavily. Nevertheless it gives a hint for further investigation and as such will be discussed in the last section of this chapter.

SAW Responses in Relation to the "Makes Friends Easily" Subscale of the EPI

In this case too the $\mathrm{H}_{1}(\mathrm{X})$ was rejected though a highly significant $B$ effects' $F$ indicated differences not likely to be due to chance. But the direction of the $\mathrm{H}_{1}$ was contradicted. An examination of the specific items again revealed that the label "makes friends easily" caused a false expectation of what the scale would measure.

The assumption underlying $H_{1}(X)$ was that the dogmatic person would have difficulties in establishing lasting friendships as his acceptance of others is conditional (Rokeach, 1960) and because of his tendency to judge others rather in terms of their shortcomings than in terms of their positive traits (Robbins, 1971). 
But the EPI subscale "makes friends easily" seems not to call forth responses indicating the quality of the S's friendship relations; two factors seem to be involved: (1) Ease to initiate contact, and (2) need for approval. Three sample items are given below:

23. He is always making new friends and meeting new people. 116. He wants everyone to like him. 257. He can easily make a friend of a complete stranger. The one who scores high on this scale indicates something quite different from being able to establish good friendship relations, which has been assumed because of the label and which led to $\mathrm{H}_{1} \mathrm{X}$; He not only wants everyone to like him--most of us want to be liked-he needs everyone to like him; he needs this probably because he cannot like himself and therefore needs others to like him, to prove that he is likeable; this reassurance he needs rather often as his self hate can only be supressed for a time. Another point is that he makes friends out of others: he does not become friends with people because they have common grounds and sympathy with one another--he makes them feel that he is a "nice guy", which implies that he adjusts to them, plays a role; but this image can only be held up in a superficial kind of "friendship". Therefore new "friendships" are always initiated in order that older ones shall not become so deep that the role playing becomes too strenuous on the part of the actor or that the role is seen through. 
It is questionable whether this person enjoys putting on a role. It is more likely that he looks down on himself for doing so and by that reinforces his self hate. As others are involved in this vicious circle, as he is dependent on them in needing their approval, he comes to hate them too. This he cannot openly admit-he needs approval--and therefore says "I care for you so deeply", but his body-language tells a quite different story. Hence the unease in meeting that kind of people.

Analysis of variance $X$ shows that this personality is related to narrow extremism. And it is rather probable that the individual uses his object of extremism--"E. G. White" in this case--to express his hostility.

\section{Suggestions for Further Research}

Narrow extremism as measured by the SAW seems to be based on three factors:
a. Commitment,
b. Dogmatism,
c. Hostility.

Factor a should be valued and even nourished as it is the one the church depends on. The only danger is that the commitment becomes so deep that other things (family, recreation, etc.) are neglected. Also flight into commitment--away from other responsibilities--should not be encouraged.

Factor b basically stems from intercommunication barriers between ones belief--disbelief subsystems. This makes possible 
the existence of contradicting beliefs and values in the dogmatic person without his being aware of it. Another consequence of the relative closedness of one belief subsystem against the other is a weakness of "perceptual synthesis (Rokeach, 1960, pp. 266ff.)." The dogmatic person has difficulties putting thoughts together, in drawing proper conclusions; he rather pulls parts out of a whole that fit into his system.

What can be done about this? It is doubtful whether basic changes can be brought about in the adult dogmatic individual; but there seems to be a relation between creativity and openmindedness or stated differently that it is the barriers between ones belief--disbelief systems that hinders a person from thinking creatively. This should be investigated further as if this hypothesis is confirmed, every means that enhances creativity then should build openmindedness. This then should also be modifying our methods of passing on values to the next generation by just setting up standards and expecting that they be adjusted to without questioning or modifying or violating them.

The above are long range goals and it is doubtful whether they can be reached for great parts of the population or the church. A physician besides treating the cause sometimes has to treat the symptoms too; sometimes this is the only help he can offer. The S.D.A. church could do the same in treating the dogmatic symptoms that are expressed in relation to "E. G. White". 
This might be easier than it seems to be! What has the dogmatic person to change? He has only to change one of his belief subsystems, not his whole value system, as an openminded person must do in order to change a specific view because his belief subsystems are interrelated with one another. But is the dogmatic individual not resisting change? Yes, but not so much if the new aspect is given by an authority figure and if it is presented in its consequences.

The only analysis of data where a significant interaction $F$ was found was the one with Exposure to E. G. White and "cooperative" as independent variables. It will be recalled that the "cooperative" scale more properly could be labeled as uncritical acceptance of authority. The simple effects analysis yielded significant differences between the three groups on the $10 \mathrm{w} \mathrm{B}$ (cooperative) level in relation to their exposure to E. G. White. The low A (exposure) group scored lowest on the SAW, the high A group highest. On the medium B level no significant differences were obtained. The high $B$ level analysis almost reached significant differences. But this time the low and medium A groups scored higher on the SAW and the high A group scored lower. The end result of exposure to E. G. White was that all B groups with most exposure scored the same on the SAW. The very extreme groups seemed to become less extreme the more exposure they had whereas the least extreme groups scored higher with more exposure so that in the end both extremes arrived where the medium group has been. 
Attention should be given to the fact that on the low A level the groups differed most. The more exposure they had, the more the attitudes toward "E. G. White" became balanced. Several questions come to mind at this point:

a. Why is the high B group on the low A level scoring highest on the SAW? Do they get an impression of "E. G. White", that more exposure to E. G. White does not allow for?

b. Why is the low B group on the low A level scoring lowest on the SAW? Do they react--over-react perhaps-to what they perceive as unreasonable attitudes toward "E. G. White"?

c. If we think in terms of commitment, dogmatism, and hostility--which factor is lowered in the high B group and which is raised in the low $B$ group by additional exposure to E. G. White?

d. Do all E. G. White books call forth the same attitudes? Or do different books have a different influence? What is the difference between books E. G. White has written as a book and those books where others have compiled statements from her?

Especially the last question should be investigated. It is hypothesized that these books (compilation) have a detrimental effect on the dogmatic individual. For the Seventh-day Adventist E. G. White is likely to be the highest authority. The dogmatic church member especially will take whatever she stated. In the 
books she wrote E. G. White gave the full context. But in compilations only the written context is given and not the context of time, circumstances, and reasons why she made the special statement.

Even if the full context were given to selected statements, it is hard for the closedminded person to put things together. They do better when they are told what the implication is of such and such a statement. Rokeach found this and stated that the dogmatic person is more comfortable with answers given on a "silver-platter". But once the dogmatic person is familiar with one thing he knows well how to apply it.

It is strange that no relationship seems to exist between dogmatism and intelligence. But creativity and intelligence do not necessarily go together either.

Rokeach (1960) found that in most aspects that were relevant to dogmatism the medium groups responded or reacted the same way as the high dogmatic groups did. This is affirmed by the finding that no significant difference existed between high and medium groups on the SAW but between high and low, and medium and low groups. This shows how important the above questions are, as the dogmatic reaction can be expected in two thirds of the population of this study.

What can be done about the part hostility plays in this narrow extremism? This seems to be the worst part in the whole matter and the most dangerous one for the church. It is the opposite of what the "good news"mean but displays the image of 
Itself to be "Christian" in the fullest sense. The problem about this factor in extremism is its inbuilt tendency to be reinforced. What is needed seems to be a therapeutic relationship within which the hostile church member can grow. The church only can accomplish that when the fellow church members are made aware of what is needed for the hostile church member: an accepting, caring warmth. This therapeutic relationship might best be reached through group counseling.

Further research in this specific area is needed to explore whether the above tentative conclusions and hypotheses will be affirmed or not. Special attention is called to the problem of "E. G. White books" compiled by third persons. A basic solution is long overdue and could probably prevent much damage to the church. 
A P P E N D I X 
ANNOUNCEMENT SHEET ARTICLE 


\section{SEMINARY STUDENT ANNOUNCEMENTS SHEET}

April 30, 1973

MR. RANIER ISECKE, a graduate student is conducting a study related to the attitude of S.D.A. theological student toward the writings of E. G. White. A random sample is essential to the success of the study. Those selected will be notified by letter. It will be appreciated if you can participate. 
LETTER OF INVITATION 
May 3, 1973

Rainer Isecke

Beechwood Court E-51

Berrien Springs, Mich.

Phone: 471-7213

Dear fellow student:

This letter is to inform you that you have been chosen as one to represent the Seminary in the research study that was described in the announcement sheet last Monday, April 30th, and approved by Dean W.G.C. Murdoch.

The study is concerned with isolating factors which may influence ones attitudes toward the place of the writings of E. G. White in the Seventh-day Adventist Church.

The study will be conducted in the Gold Room in Meier Hall, May 11 , 1973 at 9 a.m.

Please be sure to come in time as it is important for this study that each chosen representative participates in it. It is hoped that the results of the study may be of benefit to you in your future ministry.

Please bring this invitation with you to the session in order that I can check who was able to follow the invitation. Please don't forget as there is no possibility for me to check it otherwise as you will not be asked to indicate your name on the answer sheets.

Your friendly cooperation will be deeply appreciated.

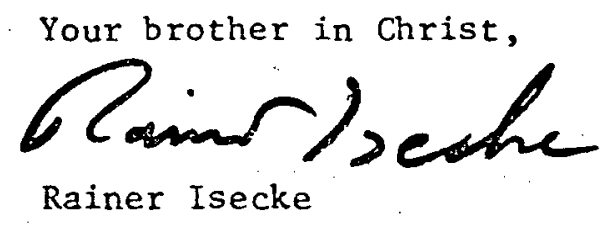

P. S. If it is impossible for you to be there will you please call me as soon as possible? 
QUESTIONNAIRE OF EXPOSURE TO E. G. WHITE 
Please respond to the following questions, 1-4, by circling the letter $(a, b, c, \ldots)$ of the correct answer:

1. Sex ?. . a. Kale b. Female

2. Age ? - a. 22 or younger b. $25-24$ c. $25-26$ d. 27-28 e. 29-30 f. $31-32$ g. $33-34$ h. $35-36$

1. 37 or older

3. Race? - a. White b. Black c. Oriental d. White-Black e. White-Oriental f. Black-Oriental g. Other

4. Are your parents Seventh-day lidventists ? . a. Neither of them b. Father c. liother d. Both parents

Please respond to the following items, 5-6, by providine the correct number above the given line:

5. Number of years you atterded S.D.A. "Schools, excluaing Andrews University Seminary:

6. Number of quarters you have attended Andrews University seminary, including the present quarter: . . . . . .

Flease respond to the following questions, $7-8$, by circling the letter ( $a, b$, or $c$ ) of the correct answer:

7. Have you taken the course CH57C-HISTORY OF THE SEVEHTH-DAI ADVENIIST CHURCH ? . . a. No

b. This quarter

c. During a past quarter

8. Have you taken the course

T570-PEOPHETIC GUIDAITE ? . . . a. No

b. This quarter

c. During a past quarter

The following items represent E.G. White books (9-70) and books about $\mathrm{E} . \mathrm{G}$. White $(71-93)$; please indicate by circling $a, b$, or $c$, if you have read that book

a. partialiy, b. fully, or c. more than once.

9. $a$ b c Testimonies for the Church, Vol. I

10. a b c "

11. a i c $\mathrm{c}$ " $"$ ", Vol. III

12. a b c " $"$ " $"$ " Vol. IV

13. a b c

14. a b c

15. a b c

16. a b c

17. a b c

18. a b c

19. a b c

20. a b c

21. a b.c Acts of the Apostles

22. $a$ b c Great Controversy 


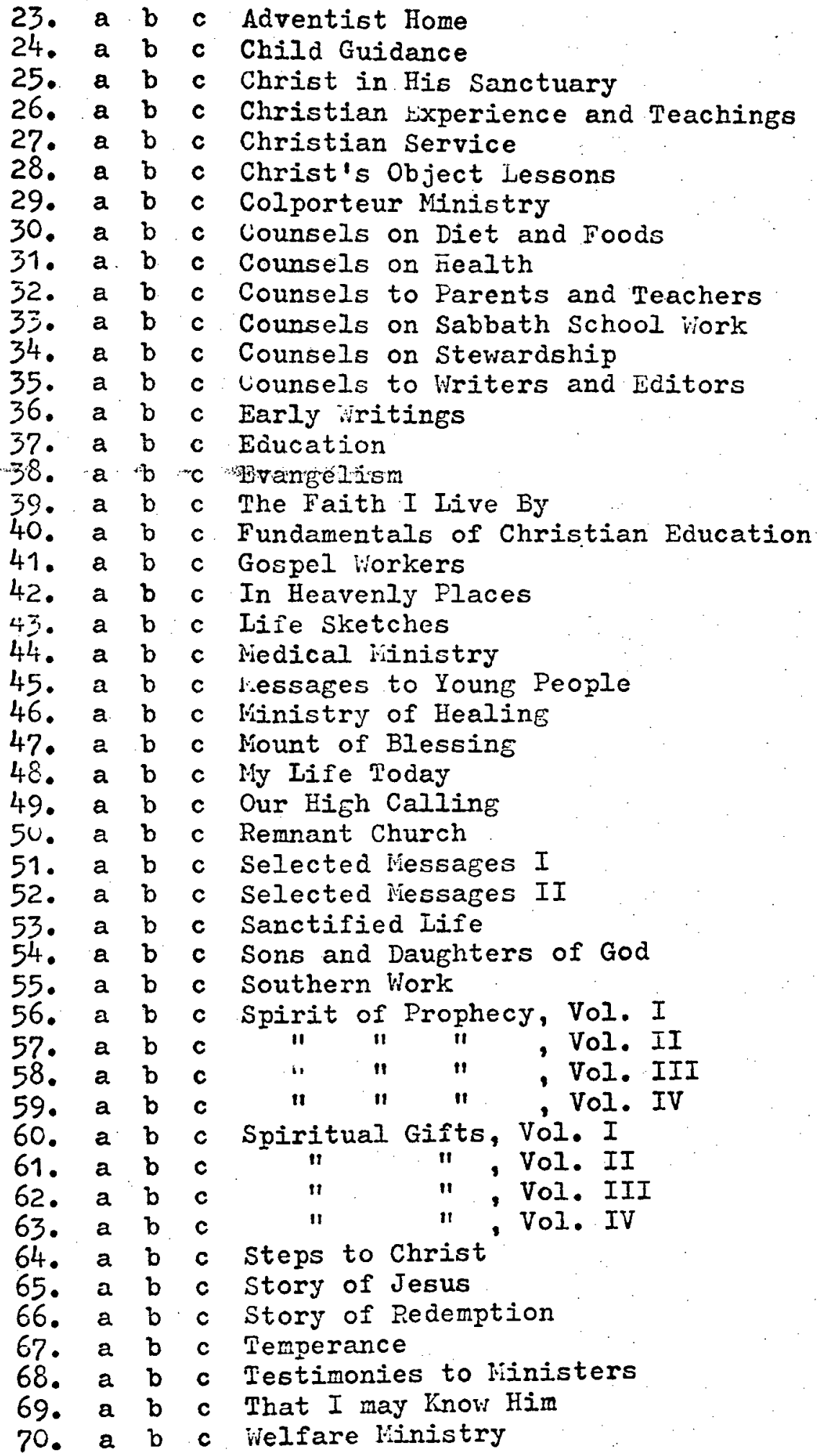


71. a b c Abiding Gift of Prophecy, Arthur G. Daniells

72. a b c Angel Over Her Tent \& Other Stories About Ellen G. ihite, D. A. Delafield

73. $a$ b c A Prophet Among You, T. Housel Jemison

74. a b c Believe His Prophets, Denton Edward Rebok

75. a b c Christian Experience and Views of Ellen G. White,

76. $a$ b c Ellen G. Hite and the SDA Church, D. A. DelafieId

77. $a$ b c Ellen G. White and Her Critics, F. D. Nichol

78. a b c Ellen G. White Messenger to the Remnant, A. I. White

79. a b c Ellen G. White Prophet of Destiny, Rene Foorbergen

80. a b c Eruitage of Spiritual Gifts, Lewis Harrison Christian

81. $a b$ c Gift of Prophecy in the Seventh-day Adventist Church, William A. Spicer

82. a b c His Fessenger, Ruth'theeler

83. a b c I'd Like To Ask Ellen Wite, Fllen G. White Estate

84. a b c Iife and Teachings of Ellen G. White, White Estate

85. a b c Iife Sketches of Ellen G. White, Pacific Press

86. a b c Life sketches of James and Ellen inite, steam Press

87. a b c Sister inite, Arthur i. Spalding

88. $a$ b c Stories of Iittle Ellen, Helen M. Johnson and Evelyn Roose İinsmore

89. $a$ b c Stories of my Grandmother, Ella liae Robinson

90. a b c There Shines a Light, Arthur H. Spalding

91. a b c The Spirit of Prophecy, Willian A. Spicer

92. a b c The Testimony of Jesus, Francis liciellan Wilcox

93. $a$ b c Why I Believe in Mirs. E. G. White, F. D. Nichol 
SCALE OF ATTITUDES TOWARD "E. G. WHITE"

FORM A 
The following are statements which reflect the thinking and feeling of many seventh-day Adventists concerning their views and knowledge of E.G. White and her writings. Different, sometimes even opposing viewpoints are given; you may find yourself agreeing strongly with some of the statements, disagreeing just as strongly with others, and perhaps uncertain about others; the best answer to each statement on the following pages is your PERSONAL OPINION. Whether you agree or disagree with any statement, you can be sure that many seventh-day diventists feel the same as you do.

Mark each statement in one of the columns on the right according to how much you agree or disagree with it. Please mark every one. The columns $(1-7)$ Eive a continuur ranging from STRONGIY AGREE (1), to STROINGLY DISAGREE (7).

An example is given below:

60. A Christian in all situations should obey the law of the country he is living in. .

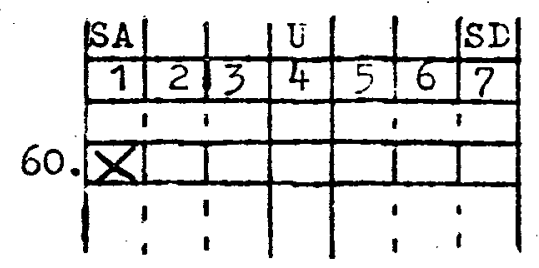

If you would cross off

colum 1, as was done in the example, this would indicate that jou STRONGLY AGREE with this statement;

colum 2 would indicate that you AGREE ON THE WEOIE with it;

column 3 would indicate that you AGIEE A IIITIE with this statement;

column 4 would indicate that you are UICERTAIiv whether you agree or disagree with it;

column 5 would indicate that you DISAGRie A IIITL with this statement;

column 6 would indicate that you DISAGREN CII THE WISIE with it;

column 7 would indicate that you STEOIGLY IISAGRIE with this statement. 
1. One of the basic tasks of missionary efforts today should be to make people acquainted with E.G. White's writings.

2. What sets the S.D.A. Church apart from others is basically due to the impact of E.G. White. . . . . . . . . . . .

3. A person's knowledge of E.G. White's writings should be a chief criterion for selection for local church offices. . . .

4. E.G. White's statements often Ieave open different interpretations.

5. E.G. Whiters statements are always valid in the form they are written. . . . ....

6. E.G. White's statements should not be questioned, whether they are made under direct Divine influence or not. . . . . .

7. I could understand the Holy scriptures adequately without reading E.G. White's books.

8. After God had chosen E.G. White, He still allowed her to make errors. . . . . .

9. The writings of E.G. White do not have the same importance as the Holy Scriptures. -

10. E.G. White was a prophet like Daniel or John. . . . . . . . . . . . . .

11. E.G. White's reports of visions are subjectively colored. . . . . . . . .

12. From the manner in which a church member dresses and grooms himself you can see if he appreciates E.G. White or not. . . .

13. According to E.G. White, adolescents should be made aware of the danger, but given the freedom to participate in situations where they could possibly fall in sin......

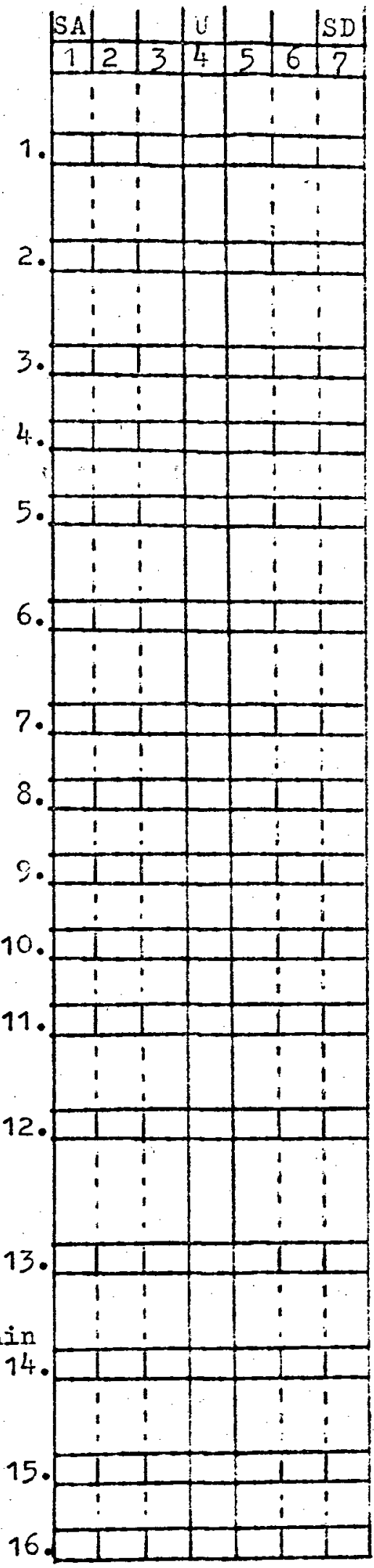

14. E.G. Wite's writings must be read by keeping in mind that she belonged to a certain culture in a certain time. ....... 14

15. Even in the time followins her first vision E.G. White was not constantly under Divine inspiration.

16. Today E.G. imite would not mind women wearing pants. 
17. A Seventh-day Adventist should not play cards because L.G. White tells us that it is not good. ......................

18. Even when written under Divine inspiration, E.G. White's statements reflect her own imagination. . . . . . . . . . . .

19. In many cases people are justified in claiming that a statement of E.G. White is no longer valid today.............

20. Nost Seventh-day Adventists would act differently if they really knew E.G. White's writings.

21. E.G. Inite's statements are so clear cut that there is no room for different interpretations.

\section{$\therefore$}

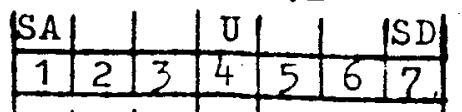

17.

\begin{tabular}{|ll|l|l|l|}
\hline 1 & 1 & & 1 & 1 \\
\hline 1 & 1 & & & 1 \\
\hline
\end{tabular}

22. According to E.G. White it is inadvisable to restrict youth to such activities where no possibility of following the wrong path can be seen. . . . . . . . . . . . . . . .

23. E.G. Ihite's basic concern with weak church members would be how to convince them that it would be for their best to change habits.

24. Eating meat, despite F.G. White's statements concerning this, is not a sin. .....

25. Even after her visions began, E.G. White made some erroneous statements concerning matters related to christian beliefs. . . .

26. If living today, E.G. White would deeply be concerned with todays style of dressing and grooming in young people.

27. E.G. White was set apart from mankind in beine without sin after God gave her the first vision.

28. In spite of trying hard, E.G. imite did not wholiy succeed in living without sin.

29. E.G. White's writings should be critically evaluated like any other writings. . . .

30. $\Lambda$ person should not be baptized before he is thoroughly informed about the writings of E.G. White.

31. A person that is a good Christian, but does not live up to the standards given by $E$. G. White, should still be Given church responsibilities. . . . . . . . . . . . .

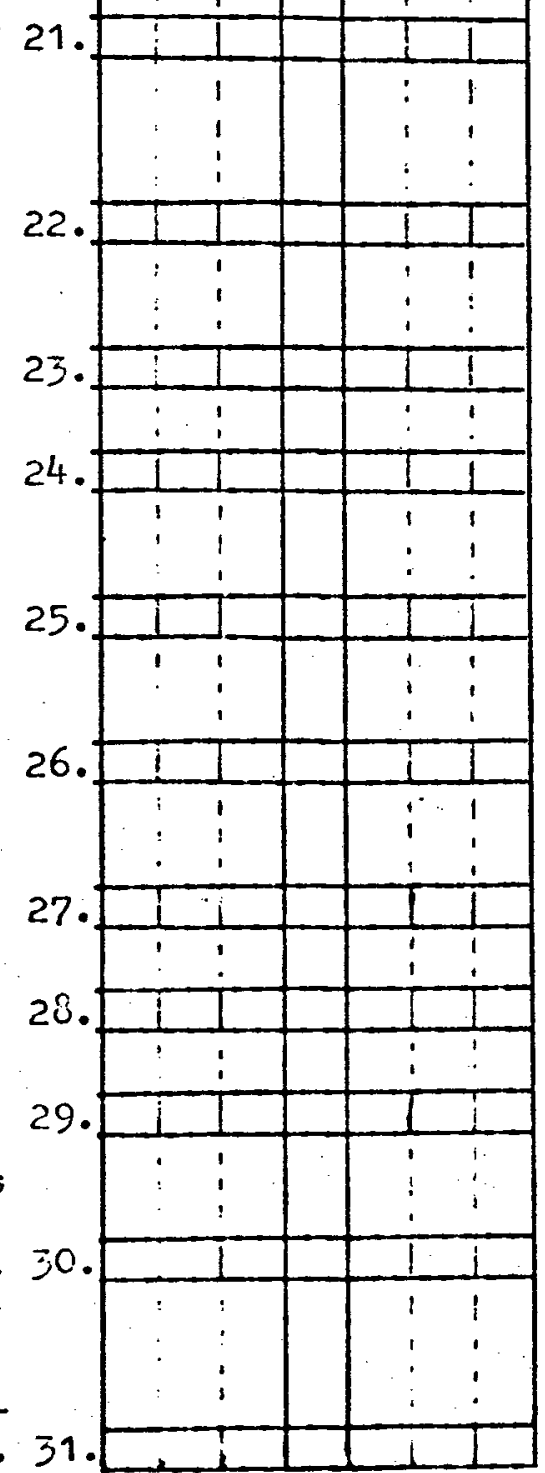


32. All of E.G. White's writings are inspired by God. . . . . . . . . . . . . .

33. Even though parents Iive in accordance with E.G. White's writings, their children may fail to become true christians. . . . .

34. If E.G. White was alive today, she would certainly discourage young men from wearing long hair.

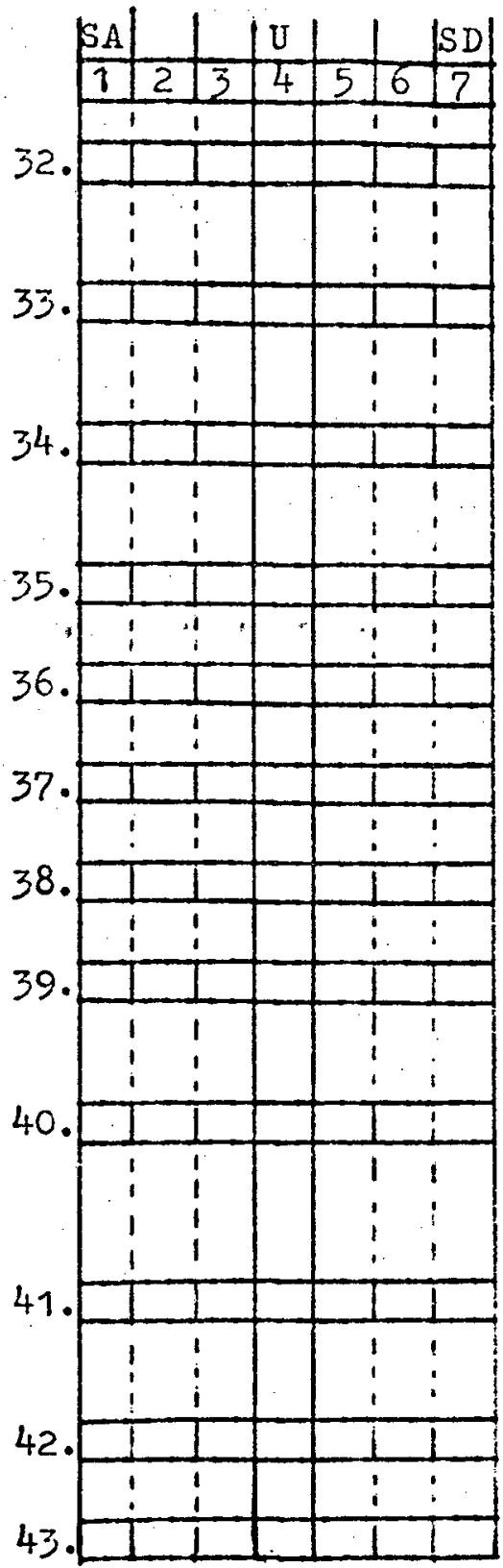

35. It should not be permissible for a person to be baptized even though he rejects. E.G. Winite.

36. I coula have become "as good a christiann I am without knowing E.G. Thite's writings.

37. God had no particular reason in choosing E.G. White as His voice. . . . . . .

38. There is no need to read E.G. Thite's books if you know your Eible.

39. To be of greatest value, E.G. White's statements should be applied Iiterally. . .

40. A Seventh-day Adventist who does not follow E.G. White's advice is a questionable Christian.

41. It should not be mandatory for a church member to accept E.G. White's interpretation of a bible text if the bible does not definitely sustain that interpretation.

42. E.G. White's basic issue is to make people happy Christians rather than to restrict theix lives. . . . . . . . . . . .

43. It is not E.G. White that makes the S.D.A. Church distinct from others. . . .... 
SCALE OF ATTITUDES TOWARD "E. G. WHITE"

FORM B 
The following are statements which reflect the thinking and feeling of many Seventh-day Adventists concerning their views and knowledge of E.G. Wite and her writings. Different, sometimes even opposing vieupoints are given; you may find yourself agreeing strongly with some of the statements, disagreeing just as strongly with others, and perhaps uncertain about others; the best answer to each statement on the following pages is your PEPSONAI OPINION. Whether you agree or disagree with any statement, you can be sure that many seventh-day didventists feel the same as you do.

Nark each statement in one ô the columns on the right according to how much you agree or disagree with it. Please mark every one. The columns $(1-7)$ give a continuum ranging from STRONGLY AGREE (1), to STROIIGLY DISAGREE (7).

An example is given below:

60. A Christian in all situations should obey the law of the country he is living in..

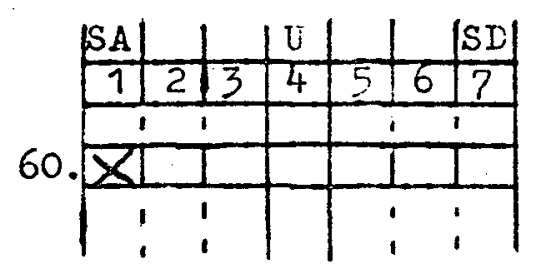

If you would cross off

column 1, as was done in the example, this would indicate that you STRONGLY AGREE with this statement;

column 2 would indicate that you

AGREE ON THE WEOLE with it;

column 3 would indicate that you

AGHEE A IITTLE with this statement;

column 4 would indicate that you are

UNCERTAIiv whether you agree or disagree with it;

column 5 would indicate that you

DISAGRIE A IITTIE with this statement;

column 6 would indicate that you

DISAGREE CIN THE WHOIE with it;

column 7 would indicate that you

STEOHGLY DISAGREE with this statement. 
1. In our mission efforts today the distribution of E.G. White's books should be of minor importance.

2. It is not E.G. White that makes the S.D.A. Church distinct from others. . .

3. A person's knowledge of E.G. White's writings should not be a chief criterion for selection for local church offices. .

4. E.G. White's statements are so clear cut that there is no room for different interpretations.

5. Today E.G. White wovld necognime that sone of her statements as they stand are not valid any longer.

6. UnIy statements which E.G. White made under direct Divine influence can be taken without question. .................

7. Without reading E.G. White's books, I could not understand the Holy Scriptures as adequately as I do.

8. After God had chosen E.G. White, He never would have allowed her to make an error. .

9. The writings of E.G. White should be looked at as having the same importance as the Holy Scriptures.

10. E.G. White cannot be looked at as being a prophet Iike Daniel or John. . . . . . .

11. E.G. White's reports give the objective reality of her visions.



12. From the outward appearance of a church member you cannot draw conclusions about his attitudes toward E.G. White. . . . . .

13. According to E.G. Mite, adolescents should be kept away from situations where they can possibly fall into sin. . . . . . . . .

14. Being familiar with E.G. White's writings makes me feel good. ........... .

15. In the time folloring her first vision E. G. Winite was constantly under Divine inspiration.

16. According to E.G. Winite, women should not wear pants. 
17. When E.G. White advises not to play cards, she refers only to the habit of playing excessively for high risk, and not to that kind of card playing that people do in spending some of their leisure time. . . .

18. If you know E.G. White's writings, it is easy to point out mistakes in church members.

19. In saying that a certain statement of $E_{0} G$. White is no longer valid today because of different circumstances, a person merely tries to neglect his responsibilities.

The knowledse of E.Go White's writings does not necessarily improve a person's life-style.20.

21. H. C. White's statements often leave open different interpretations.

22. E.G. White recommends that youth should only be allowed to engage in those activities where there is no danger of following the wrong path. . . . . . . . . . . . 22 .

23. If E.G. White was alive today, she would recommend most Adventists to change their habits immediately, whether they like it or not, or to leave the church. . ......

24. Eating meat, despite knowing E.G. White's statements concerning this, is a sin. ...

25. After God gave E.G. White her first vision, she did not make an erroneous statement concerning matters related to christian beliefs.

26. If Iiving today, E.G. White would not be concerned too much with todays style of dressing and grooming in young people. . .

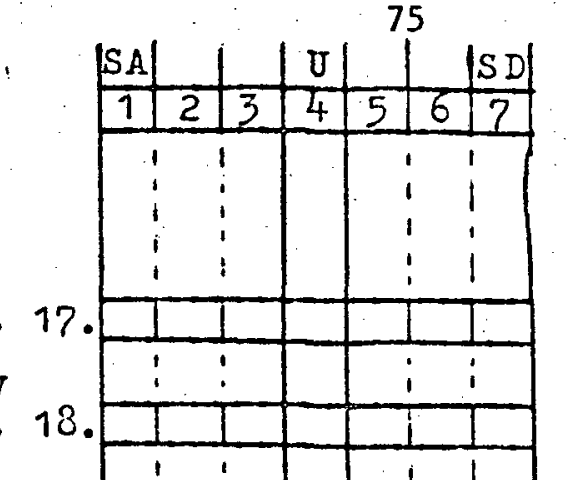

27. After God gave her the first vision, E.G. White still was a sinner like any other human being.

28. E.G.wite is an example of the possibility to live without sin if only one tries hard enough. . . . . . . . . . . . . . .

29. E.G. White's statements should be accepted as they stand. .................. 29

30. It is not necessary that a person be thoroughly informed about the writings of E.G. White before he is baptized. . . .

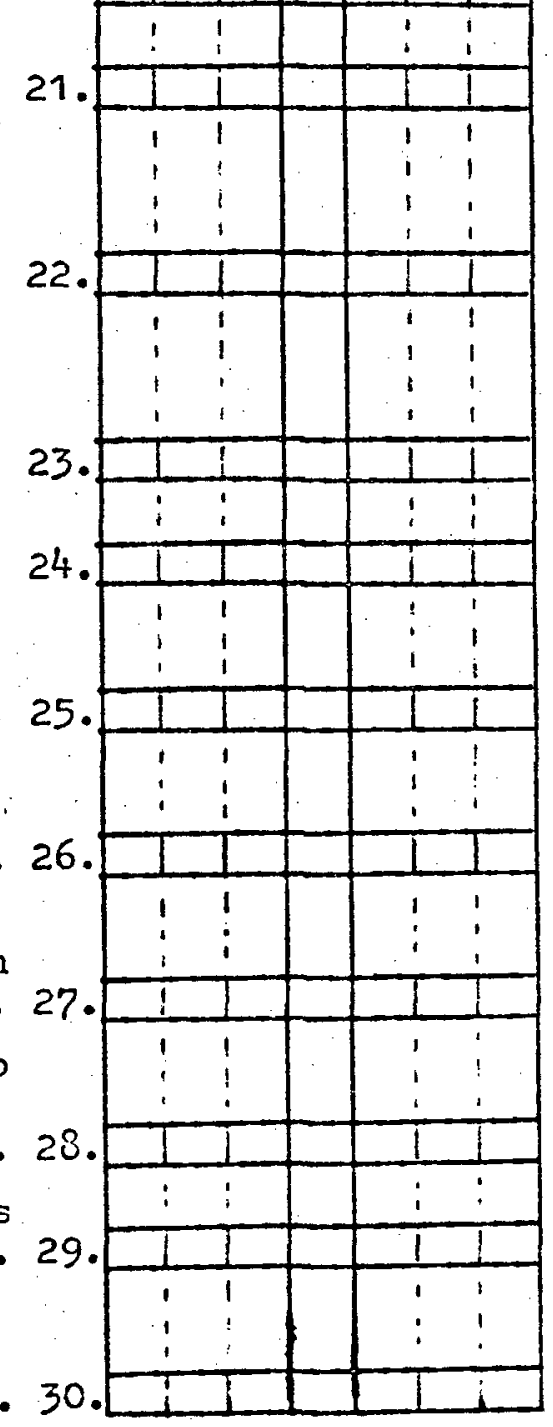


31. Despite being a good Christian, a person that does not Iive up to the standards given by E.G. White should not hold church responsibilities. . . . . . . . . . 31.

52. In some of her writings E.G. White expressed her own opinion. . . . . . . . . 32

33. If parents really Iived according to E.G. White's advice, their chilaren would rarely fail to become true Christians. ......

34. If she was alive today, E.G. White would not object to young men wearing long hair. . . 34.

55. It should be permissible for a person to be baptized even though he rejects $\mathrm{E} . \mathrm{G}$. Bhite. 35

36. I could not have become as good a Christian as I am without lnowing E.G. White's writings.36.

37. God chose E.G. ihite because of her efforts to live without sinning. . . . . . . . 37.

38. ihen reading E.G. White books I often feel that certain persons don't read her books because they fear changes in their lives will be needed.

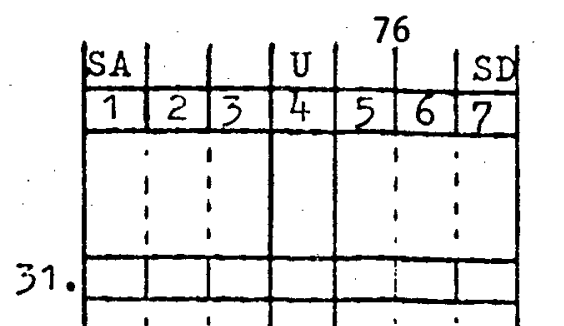

39. E.G. White's statements often concern a special situation and then cannot be applied literally.

40. A seventh-day Adventist who does not follow E.G. ihite's advice is not therefore a questionable christian. . . . . . . 40

41. A Seventh-day Adventist should accept E.G. White's interpretation of a bible text though the bible does not give an interpretation of that text. . . . . . . . . . . . .

42. To help church nlembers look at a situation in the light of $\mathrm{E} . \mathrm{G}$. Hite's statements gives me a feeling of superiority. . ....... .

4j. What sets the S.D.A. Church apart from others is basically due to the impact of E.G. inite.

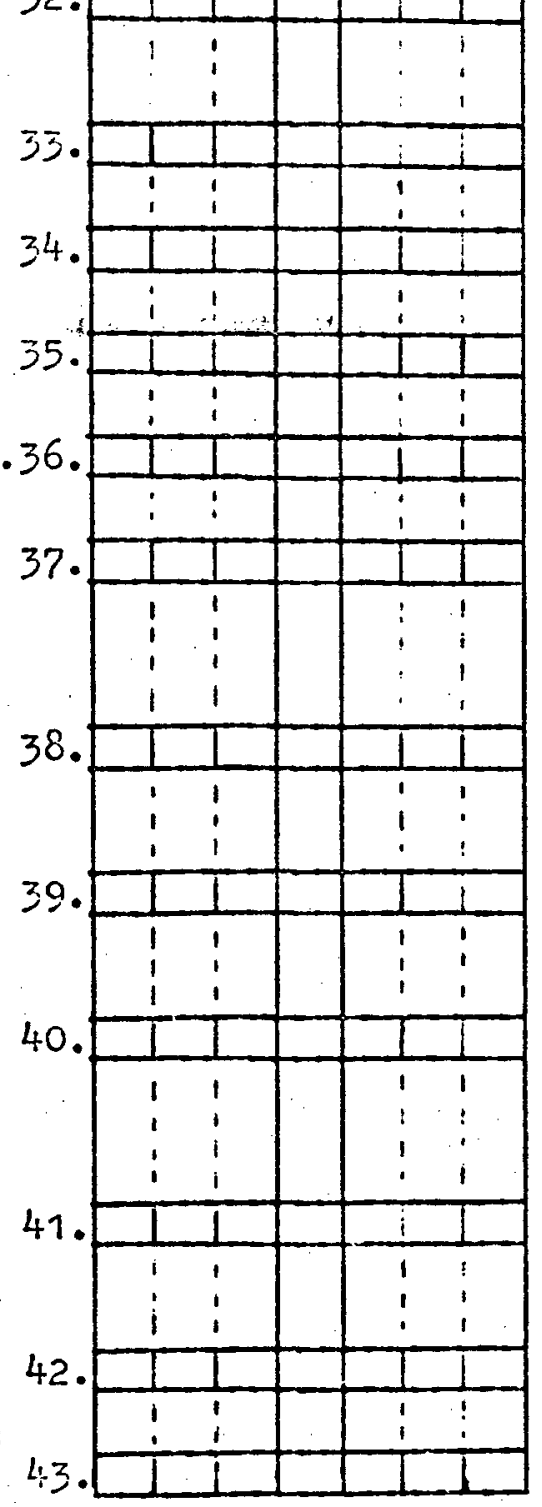


SCALE OF ATTITUDES TOWARD "E. G. WHITE"

FINAL FORM 
The following are statements which reflect the thinfing and feeling of many Seventh-day Adventists concerning their views and bnowledge of E.G. Shite and her writings. Different, sometimes even opposing viewpoints are given; you may finc yourseli agreeing strongly with some of the statements, disagreeins just as strongly with others, and perhaps uncertain about others; the best answer to each statement on the following pages is jour FERSO:i I CPINIOI. inether you agree or disagree with any statement, you can be sure that many Seventh-day Adventists feel the same as you do.

Hark each statement in one of the columes on the risht according to how much you agree or cisagree with it. Flease mark every one. The columas $(1-7)$ Give a continuus ranöins from STRONGIY AGREE (1), to STROIFGI DISAGREE (7).

An example is given below:

60. A Christian in all situations shoula obey the law of the country he is living in.



If you would cross off

column 1, as was aone in the example, this would indicate that you STROIGIY AGREe with this statement;

column 2 would indicate that you SCREE ON THE VHOLE with it;

column $j$ would indicate that you AGREE A IITiII with this statement;

column 4 would indicate that you are UiCingsili whether you agree or disagree with it;

colum 5 would indicate that you DISAGREE A IIDIF with this statement;

colums $E$ yould indicate that you

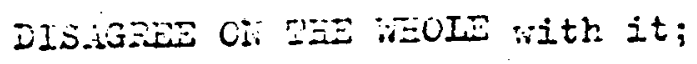

column 7 woulc indicate that you STROKGLY DISAGRE: :itr this statement. 
1. In our mission efforts today the distribution of E.G. White's books should be of minor importance.

2. A person's knowledge of N.G. Uhite's writings should not be a chief criterion for selection for local church offices. . . . . . . .

3. E.G. White's statements are so clear cut that there is no room for different interpretations.

4. Ioday E.G. Thite would recognize that some of her statements as they stand are not valid any longer.

5. Orily statements "which T.G. White madc under direct Divine influence can be talien without question.

6. Without reading E.G. White's bools, I could not understand the Holy Scriptures as adequately as I do... . . . . . . . .

7. The writings of E.G. White should be looked at as having the same importance as the Holy Scriptures. . . . . . . . . .

8. E.G. White cannot be looked at as being a prophet like Janiel or John. . . . . .

9. E.G. White's reports of visions are subjectively colored.

10. From the outward appearance of a church nember you cannot draw conclusions about his attitudes toward E.G. lihite. . . . . .

11. According to E.G. Inite, adolescents should be made aware of the danger, but given the freedom to participate in situations where they could possibly fall in sin. . . . .

12. Being familiar with E.G. White's writings nakes me ieel sood. . . . . . . . . .

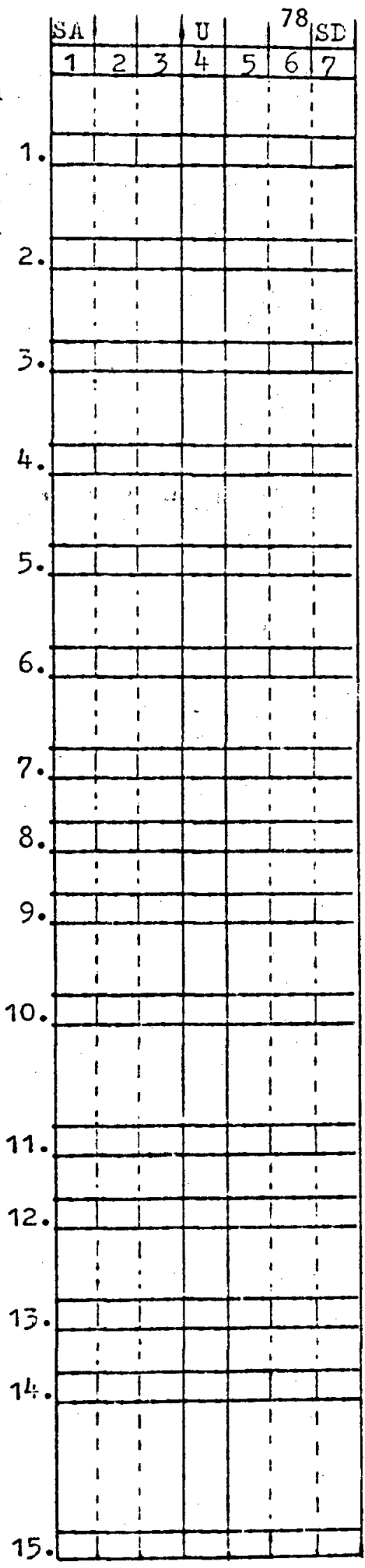

13. In the time following her first vision E.G. Uhite was constantly under Divine inspiration. . . . . . . . . . .

14. Accordin wear pants.

15. When E.G. Thite advises not to play caras, she refers only the habit of playing excessively for high rish, and not to that lind of card playing that people do in spending some of their leisure time. . . . 
16. If you lnow I.G. inite's writings, it is easy to point out mistalies in church members.

17. In saying that a certain statement of E.G. ihite is no longer valid today because of different circumstances, a person merely tries to neglect his responsibilities.

18. The knowledge of E.G. White's writings does not improve a person's life-style. . . . . 18.

19. E.G. Thite's statements often leave open different interpretations.

20. E.G. Wite recommends that youth should only be allowed to engage in those activities where there is no anger of following the wrong path. . . . . . . . . . . . .

21. If E.G. Thite was alive today, she would recomend most idventists to change their habits immediately, whether they like it or not, or to leave the church. . . . . . 21

22. Eating meat, despite E.G. White's statements concerning this, is not a sin. . . . . 22

23. After God Gave E.G. White her first vision, she did not make an erroneous statement concerning matters related to christian beliefs.

24. If living today, E.G. White would not be concerned too much with todays style of dressing and grooming in young people.



25. E.G. Thite is an example of the possibility to live without sin if only one tries hard enough. . . . . . . . . . . . 25.

26. E.G. White's statements should be accepted as they stand. . . . . . . . . . 26.

27. It is not necessary that a person be thoroughly informed about the writings of E.G. White before he is baptized. . . . . . 27

28. Despite being a good Christian, a person that does not live up to the standaras given by E.G. White should not hold church responsibilities.

29. All of I.G. Thite's writinss are inspired by God. • • • • • • • • • • • •

30. If parents really lived according to E.G. White's aavice, their children would rarely fail to become true christians. ..... 
31. If she was alive today, E.G. White would not object to young men wearing long hair. . .

32. It should be permissible for a person to be baptized even though he rejects E.G. Vhite.

33. I could not have become as good a christian as I am without lnowing E.G. White's writings.33.

34. God chose E.G. Thite because of her efforts to live without sinning.

35. There is no need to read $\Xi . G$. White's books if you lnow your Eible. . . . . . . . 35.

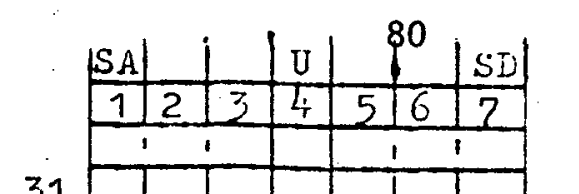

6. E.G. ihite's statements often concern a special situation and wen cantot be applied literaliy.

37. A Seventh-cay Adventist who does not follow E.G. Vinite's advice is a questionable Christian.

38. A Seventh-cay Adventist should accept E.G. mite's interpretation of a bible text though the bible does not give an interpretation of that text................

39. Even after her visions began, E.G. Uhite made some erroneous statements concerning matters related to christian beliefs. .

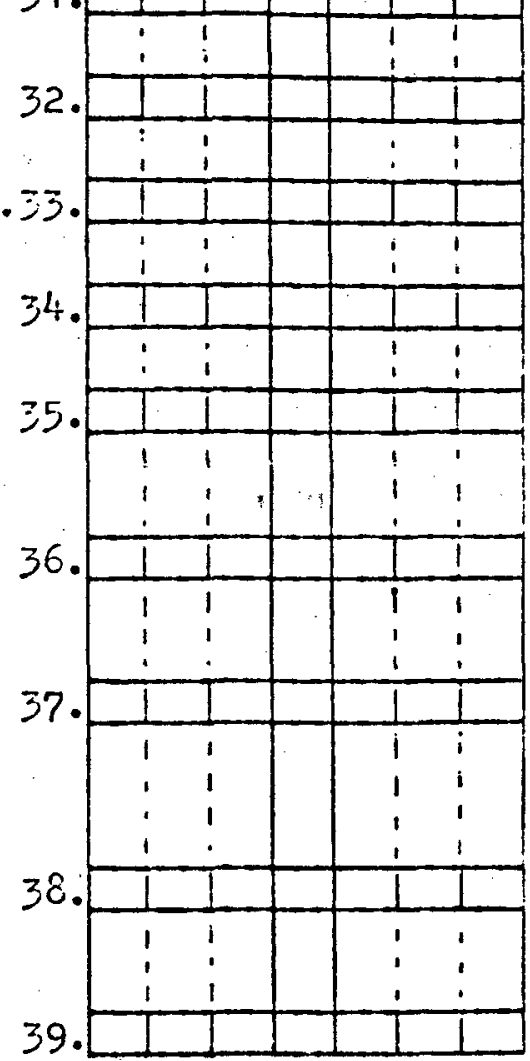


B I B L I O G R A P H Y 
Adorne, Theodor W.; Frenkel-Brunswik, Else; Levinson, Daniel $\mathrm{J} . ;$ and Sanford, Nevitt R. The Authoritarian Personality. New York: Harper \& Brothers, 1950.

Allport, Floyd $\mathrm{H}$. Theories of Perception and the Concept of Structure. New York: John Wiley \& Sons, Inc., 1955.

Bartley, Samue1 H. Principles of Perception. New York: Harper \& Brothers, 1958.

Bruner, Jerome S., and Postman Leo." "Symbolic Value as an Organizing Factor in Perception." Journal of Social Psychology, XXVII (1948), 203-8.

Buros, Oscar K., ed. The Seventh Mental Measurements Yearbook. Highland Park, New Jersey: The Gryphon Press, 1972.

Centers, Richard. "Evaluating the Loved One: The Motivational Congruency Factor." Journal of Personality, IXL (1971).

Erikson, Erik H. Childhood and Society. 2nd ed. New York: Norton, $196 \overline{3 .}$

Ferguson, George A. Statistical Analysis in Psychology and Education. 3rd ed. New York: McGraw-Hill Book Company, 1971.

Gibson, James J. The Perception of the Visual World. Boston: Houghton Mifflin Company, 1950.

Graff, Robert W., and Ladd, Clayton E. "POI Correlates of a Religious Commitment Inventory." Journal of Clinical Psychology, XXVII (October, 1971), 502-4.

Hanson, David J., and Bush, Anne M. "Anxiety and Dogmatism." Psychological Reports, XXIX (October, 1971).

Havighurst, Robert J. Developmental Tasks and Education. 3rd ed. New York: Mc Kay, 1972 .

Hebb, Donald 0. The Organization of Behavior: A Neuropsychological Theory. New York: John Wiley \& Sons, Inc., 1949. 
Kelley, Dean M. Why Conservative Churches are Growing. New York: Harper and Row, Publishers, 1972.

Laszlo, John P., and Rosenthal, Robert. "Subject Dogmatism, Experimenter Status, and Experimenter Expectancy Effects." Personality: An International Journa1, I (1971), 11-23.

Maslow, Abraham H. Toward a Psychology of Being. Princeton, N.J.: D. Van Nostrand Co., Inc., 1968.

Oswald, Robert M. "The Relationships Between Certain Personality Variables and Conservative, Moderate, and Liberal Theological Beliefs." Unpublished Ph.D. dissertation, North Texas State University, 1970.

Piaget, Jean. The Moral Judgment of the Child. Translated by Marjorie Gabain. Free Press of Glencoe, 1932.

Robbins, Gerold E. "Dogmatism and the Information Gathering Aspects of Person Perception." Unpublished Ph.D. dissertation, St. Louis University, 1970.

Robinson, John P., and Shaver, Phillip R. Measures of Social Psychological Attitudes. Ann Arbor: Survey Research Center, Institute for Social Research, 1969.

Rokeach, Milton. The Open and Closed Mind; Investigations into the Nature of Belief Systems and Personality Systems. New York: Basic Books, 1960.

Thompson, Ellen K. "Attitude Comparison between U.S. and Norwegian Seventh-day Adventist Academy Students towards the Writings of E. G. White." Unpublished Project Report for M.A. degree, Andrews University Graduate Schoo1, 1971. 